\title{
Article \\ Mechanistic Insights into Potassium-Conferred Drought Stress Tolerance in Cultivated and Tibetan Wild Barley: Differential Osmoregulation, Nutrient Retention, Secondary Metabolism and Antioxidative Defense Capacity
}

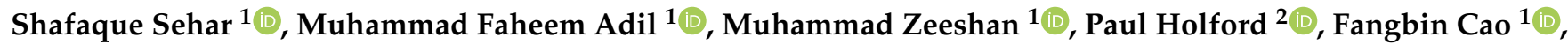 \\ Feibo Wu $1,3,4$ (D) and Yizhou Wang 1,4,*(D)
}

1 Department of Agronomy, Zijingang Campus, College of Agriculture and Biotechnology, Zhejiang University, Hangzhou 310058, China; 21516206@zju.edu.cn (S.S.); dradilfaheem@zju.edu.cn (M.F.A.); 11616102@zju.edu.cn (M.Z.); caofangbin@zju.edu.cn (F.C.); wufeibo@zju.edu.cn (F.W.)

2 Hawkesbury Campus, School of Science and Health, University of Western Sydney, Penrith, NSW 2751, Australia; p.holford@westernsydney.edu.au

3 Jiangsu Co-Innovation Center for Modern Production Technology of Grain Crops, Yangzhou University, Yangzhou 225009, China

4 Provincial Key Laboratory of Crop Germplasm, Zhejiang University, Hangzhou 310058, China

* Correspondence: wangyizhou@zju.edu.cn

Citation: Sehar, S.; Adil, M.F.; Zeeshan, M.; Holford, P.; Cao, F.; Wu, F.; Wang, Y. Mechanistic Insights into Potassium-Conferred Drought Stress Tolerance in Cultivated and Tibetan Wild Barley: Differential

Osmoregulation, Nutrient Retention, Secondary Metabolism and Antioxidative Defense Capacity. Int. J. Mol. Sci. 2021, 22, 13100. https:// doi.org/10.3390/ijms222313100

Academic Editor: Esther M. González

Received: 27 September 2021

Accepted: 2 December 2021

Published: 3 December 2021

Publisher's Note: MDPI stays neutral with regard to jurisdictional claims in published maps and institutional affiliations.

Copyright: (c) 2021 by the authors. Licensee MDPI, Basel, Switzerland. This article is an open access article distributed under the terms and conditions of the Creative Commons Attribution (CC BY) license (https:/ / creativecommons.org/licenses/by/ $4.0 /)$

\begin{abstract}
Keeping the significance of potassium (K) nutrition in focus, this study explores the genotypic responses of two wild Tibetan barley genotypes (drought tolerant XZ5 and drought sensitive XZ54) and one drought tolerant barley cv. Tadmor, under the exposure of polyethylene glycol-induced drought stress. The results revealed that drought and $\mathrm{K}$ deprivation attenuated overall plant growth in all the tested genotypes; however, XZ5 was least affected due to its ability to retain $\mathrm{K}$ in its tissues which could be attributed to the smallest reductions of photosynthetic parameters, relative chlorophyll contents and the lowest $\mathrm{Na}^{+} / \mathrm{K}^{+}$ratios in all treatments. Our results also indicate that higher $\mathrm{H}^{+} / \mathrm{K}^{+}$-ATPase activity (enhancement of 1.6 and 1.3-fold for shoot; 1.4 and 2.5-fold for root), higher shoot $\mathrm{K}^{+}$(2 and 2.3-fold) and $\mathrm{Ca}^{2+}$ content (1.5 and 1.7-fold), better maintenance of turgor pressure by osmolyte accumulation and enhanced antioxidative performance to scavenge ROS, ultimately suppress lipid peroxidation (in shoots: $4 \%$ and $35 \%$; in roots $4 \%$ and $20 \%$ less) and bestow higher tolerance to XZ5 against drought stress in comparison with Tadmor and XZ54, respectively. Conclusively, this study adds further evidence to support the concept that Tibetan wild barley genotypes that utilize $\mathrm{K}$ efficiently could serve as a valuable genetic resource for the provision of genes for improved $\mathrm{K}$ metabolism in addition to those for combating drought stress, thereby enabling the development of elite barley lines better tolerant of abiotic stresses.
\end{abstract}

Keywords: drought stress; antioxidant enzymes; osmolytes; ATPase activity; secondary metabolism; drought responsive gene expression

\section{Introduction}

Due to global warming and subsequent climatic abnormalities, plants have evolved to live in environments where they are often exposed to a wide array of stresses such as drought, salinity, waterlogging and extreme temperatures [1,2]. Conspicuously, drought stress, in particular, causes multidimensional deleterious effects on plant growth, development and productivity. On a global scale, careful projections indicate that drought alone will affect more than $50 \%$ of the arable lands by the year $2050[3,4]$. To acclimatize water scarcity, plants go through various events at morphological (reduced biomass and nutrient uptake), physiological (reduced photosynthesis, altered transpiration and stomatal activity, noticeable reduction in cell growth), biochemical (accumulation of osmolytes, reduced carbohydrates metabolism and increased oxidative enzyme activity), and molecular level [5]. 
Despite a large number of studies, our understanding of the mechanisms of drought tolerance in barley is still not comprehensive due to the complexity of interactions involved in the physio-biochemical and molecular processes [6]. One of the most cost-effective solutions for sustainable production in water-limiting areas is genetic improvement for higher drought tolerance that could be achieved by understanding the underlying mechanism and identifying the associated genes.

One of the main mechanism plants use to combat drought stress is the maintenance of normal cellular physiology through osmotic adjustment [1], which include the synthesis of new metabolites (such as callose, chitinase, phenols and flavonoids), and accumulation of osmolytes (such as proline, glycine and betaine), which interplay in protein solubilization and also share a pivotal role as reactive oxygen species (ROS) scavengers [7,8]. Although required for cell signaling, higher concentrations of ROS can instigate lipid peroxidation and degradation of vital proteins, lipids, and nucleic acids $[8,9]$. Thereby, plants have devised several enzymatic mechanisms including superoxide dismutase (SOD), catalase (CAT), and ascorbate peroxidase (APX), to persist against the oxidative damage caused by resultant ROS [10]. Leaf size reduction is another strategy adopted by plants that can directly influence the rate of transpiration; however, this reduction might lead to a decline in the photosynthetic activity [11]. In addition, many other biological processes and metabolic pathways involved in drought stress responses and tolerance have also been identified in gene expression studies. For example, using drought-tolerant and -susceptible accessions of barley (Hordeum vulgare L.) and wild barley (Hordeum spontaneum (K. Koch) Thell.), Guo et al. [12] identified 17 genes associated with drought tolerance that involved: carbon metabolism, the synthesis of glycine-betaine, scavenging of reactive-oxygen species, and stabilization of membranes and proteins.

Potassium (K) performs crucial functions in many physiological and biochemical activities during plant growth and development, including osmoregulation, maintenance of cytosolic $\mathrm{pH}$, stabilization of protein synthesis, neutralization of negatively charged proteins, enzyme activation, photosynthesis, phloem loading and transport as well as the efficient use of other nutrients $[13,14]$. Drought stress interrupts K diffusion in soil towards the roots, thus restricting $\mathrm{K}$ absorption [15]. Hence, maintaining adequate cellular $\mathrm{K}$ is key to drought tolerance [16] and breeding better-adapted crop varieties is the most effective approach to this. Despite the modulation of drought tolerance by K $[3,16]$, there is still a void in our understanding of whether $\mathrm{K}$ plays a role as a chemical signal between roots and leaves under drought, and whether higher $\mathrm{K}$ content is connected with better $\mathrm{K}$ retention in the leaf mesophyll. In particular, data related to genotypic differences in the tolerance of barley to combined drought and $\mathrm{K}$ deficiency stresses remain scarce.

Barley is a major cereal crop that is mainly cultivated under rain-fed conditions and, as a result, can encounter drought during the grain-filling period [3,6]. Tibetan annual wild barley (H. vulgare L. ssp. spontaneum (K. Koch) Thell.) is a precious germplasm resource, and has a rich genetic diversity that may provide elite alleles for crop improvement in contrast to cultivated barley that has lost its robustness during the domestication process, making it hypersensitive to both abiotic and biotic stresses [17]. Our previous study revealed that Tibetan wild barley XZ5 is highly effective in K uptake and translocation, especially under drought conditions [16,18], but the morpho-biochemical and molecular response to drought remains unclear. Accordingly, the present study aimed to elucidate the physio-metabolic and molecular changes in response to $\mathrm{K}$ nutrition and drought stress tolerance in Tibetan wild barley XZ5 compared with drought sensitive wild barley XZ54 and drought tolerant $c v$. Tadmor which would help better understand the mechanisms of drought tolerance and provide an effective pathway for the exploration of drought tolerant genes in a barley crop. 


\section{Results}

\subsection{Plant Growth, Chlorophyll and Photosynthetic Attributes}

XZ5 exhibits excellent drought resistance in the presence of potassium. Compared with plants in the control treatment, significant decreases were observed in shoot heights (SH), root lengths (RL) and dry biomasses (SDW: shoot dry weight; RDW: root dry weight) in the $-\mathrm{K}+\mathrm{D}$ treatment after 7 days (Table 1 , Table S1). With $\mathrm{K}$ added to the drought treatment $(+\mathrm{K}+\mathrm{D})$, the effects of PEG-induced drought were alleviated to a greater extent in XZ5 $(14 \%$, $19 \%$ and $16 \%$ improvement for SH, RL and SDW, respectively), followed by Tadmor (a $21 \%$ improvement in RDW), when compared with $-\mathrm{K}+\mathrm{D}$ treated plants. Moreover, XZ5 plants retained their root dry biomass under $+\mathrm{K}+\mathrm{D}$ closer to $+\mathrm{K}$ (control). Although, no significant difference in shoot biomass was observed in XZ54 between $+\mathrm{K}+\mathrm{D}$ and $-\mathrm{K}+\mathrm{D}$, a recovery rate of $6 \%, 10 \%$ and $14 \%$ was recorded for RDW, SH and RL, respectively. Under $+\mathrm{K}+\mathrm{D}$, relative chlorophyll contents (SPAD values), upon comparison with $-\mathrm{K}+\mathrm{D}$, had an ameliorative effect of $11 \%, 16 \%$ and $7 \%$ in XZ5, Tadmor and XZ54, respectively (Figure $\mathrm{S} 1$, Table S2). The Fv /Fm ratios of all genotypes were decreased by $2 \%, 5.6 \%$ and $9 \%$ under $+\mathrm{K}+\mathrm{D}$ than control, whereas the provision of $\mathrm{K}$ helped the plants to reduce PSII damage (up to $15 \%, 11 \%$ and $16 \%$ in XZ5, Tadmor and XZ54, respectively), against $-\mathrm{K}+\mathrm{D}$. In terms of the photosynthetic parameters, $\mathrm{Pn}, \mathrm{Gs}, \mathrm{Ci}$ and $\mathrm{Tr}$, both K deficiency treatments $(-\mathrm{K}$ and $-\mathrm{K}+\mathrm{D})$ significantly reduced all below control values (Figure S2, Table S2); for $\mathrm{XZ5}$ and Tadmor, the addition of $\mathrm{K}$ had a pronounced alleviating effect on all the recorded parameters except for $\mathrm{C}$.

Table 1. Effect of K nutrition on biomass, shoot height and root length of three barley genotypes in response to drought stress.

\begin{tabular}{|c|c|c|c|c|c|}
\hline Genotype & Treatment & $\begin{array}{l}\text { Shoot DW } \\
\left(\mu \text { plant }^{-1}\right)\end{array}$ & $\begin{array}{l}\text { Root DW } \\
(\mu g \text { plant } \\
\left.{ }^{-1}\right)\end{array}$ & $\begin{array}{l}\text { Shoot Height } \\
\text { (cm) }\end{array}$ & $\begin{array}{l}\text { Root Length } \\
(\mathrm{cm})\end{array}$ \\
\hline \multirow[t]{4}{*}{$\mathrm{XZ5}$} & $+\mathrm{K}$ & $143.4 \pm 8.94 \mathrm{ABCa}$ & $53 \pm 0.86 \mathrm{ABa}$ & $27.0 \pm 0.41 \mathrm{Ca}$ & $23.5 \pm 1.21 \mathrm{Ba}$ \\
\hline & $+\mathrm{K}+\mathrm{D}$ & $139.0 \pm 11.35 \mathrm{ABCa}$ & $51.09 \pm 1.03 \mathrm{Ba}$ & $26.2 \pm 1.06 \mathrm{Da}$ & $23.5 \pm 1.30 \mathrm{Ba}$ \\
\hline & $-\mathrm{K}$ & $123.8 \pm 9.79 \mathrm{CDb}$ & $49.97 \pm 1.70 \mathrm{BCab}$ & $24.9 \pm 0.55 \mathrm{CDab}$ & $23.3 \pm 0.81 \mathrm{Ba}$ \\
\hline & $-\mathrm{K}+\mathrm{D}$ & $119 \pm 9.35 \mathrm{CDb}$ & $45 \pm 2.35 \mathrm{Cb}$ & $23.0 \pm 0.19 \mathrm{~Eb}$ & $19.7 \pm 1.09 \mathrm{DEb}$ \\
\hline \multirow[t]{4}{*}{ Tadmor } & $+\mathrm{K}$ & $150 \pm 3.88 \mathrm{ABa}$ & $43 \pm 2.76 \mathrm{CDa}$ & $22.6 \pm 0.29 \mathrm{Ea}$ & $23.7 \pm 1.96 \mathrm{ABa}$ \\
\hline & $+\mathrm{K}+\mathrm{D}$ & $112.5 \pm 10.97 \mathrm{DEb}$ & $40 \pm 2.46 \mathrm{Dab}$ & $20.6 \pm 0.99 \mathrm{Fb}$ & $20.2 \pm 0.72 \mathrm{Db}$ \\
\hline & $-\mathrm{K}$ & $133.4 \pm 2.62 \mathrm{BCDab}$ & $38 \pm 2.27 \mathrm{DEb}$ & $21.8 \pm 0.39 \mathrm{EFa}$ & $20.5 \pm 0.41 \mathrm{Db}$ \\
\hline & $-\mathrm{K}+\mathrm{D}$ & $108.8 \pm 7.90 \mathrm{DEc}$ & $33 \pm 3.19 \mathrm{Ec}$ & $20.1 \pm 1.31 \mathrm{Fb}$ & $19.2 \pm 0.57 \mathrm{Ec}$ \\
\hline \multirow[t]{4}{*}{$X Z 54$} & $+\mathrm{K}$ & $161.6 \pm 2.52 \mathrm{Aa}$ & $56 \pm 3.45 \mathrm{Aa}$ & $29.1 \pm 0.62 \mathrm{Aa}$ & $24.7 \pm 1.66 \mathrm{Aa}$ \\
\hline & $+\mathrm{K}+\mathrm{D}$ & $88.6 \pm 8.02 \mathrm{Ec}$ & $36 \pm 1.52 \mathrm{DEbc}$ & $23.6 \pm 0.37 \mathrm{DEb}$ & $22.9 \pm 1.38 \mathrm{BCab}$ \\
\hline & $-\mathrm{K}$ & $131 \pm 8.44 \mathrm{BCDb}$ & $42 \pm 0.8 \mathrm{CDb}$ & $22.1 \pm 0.53 \mathrm{Ebc}$ & $21.5 \pm 0.93 \mathrm{Cab}$ \\
\hline & $-\mathrm{K}+\mathrm{D}$ & $89 \pm 2.30 \mathrm{Ec}$ & $34 \pm 2.16 \mathrm{Ec}$ & $21.4 \pm 0.36 \mathrm{EFc}$ & $20.0 \pm 1.48 \mathrm{Db}$ \\
\hline
\end{tabular}

Different capital and small letter(s) indicate significant differences $(p<0.05)$ among the genotypes and among the 4 treatments within each genotype, respectively. $+K,+K+D,-K$, and $K+D$, correspond to basic nutrition solution with normal $K$ of $1 \mathrm{mM} \mathrm{K}$ (BNS), $B N S+20 \%$ Polyethylene glycol 6000 (PEG) induced drought stress, BNS without K (K deficiency), and BNS without K + PEG, respectively.

\subsection{Plants $\mathrm{K}, \mathrm{Ca}, \mathrm{Mg}$ and $\mathrm{Na}$ Concentrations}

Shoots of all three genotypes subjected to $+\mathrm{K}+\mathrm{D}$ showed a significant increase in Ca uptake compared to $+\mathrm{K}$ treated plants (Table 2, Table S3). The $-\mathrm{K}+\mathrm{D}$ treatment also increased shoot Ca uptake in XZ5 but not in the other two genotypes. In the roots, the treatments had little effect on Ca concentrations. In the $+K+D$ treatment, drought reduced $\mathrm{K}$ uptake in the shoots of Tadmor and XZ54, but had little effect in XZ5 compared to $+\mathrm{K}$. In the roots of plants under $+\mathrm{K}+\mathrm{D}$ treatments, drought reduced the $\mathrm{K}$ concentration in all tested genotypes, however, the extent of $\mathrm{K}$ concentration reduction was quite distinct under $-\mathrm{K}+\mathrm{D}$. Regarding concentrations of $\mathrm{Mg}$ in the shoots, the plants under $-\mathrm{K}$ treatment tended to have higher $\mathrm{Mg}$ concentrations than plants in the two $+\mathrm{K}$ treatments. Under $-\mathrm{K}$ treatments drought reduced $\mathrm{Mg}$ concentrations in the shoots of Tadmor and XZ54 but not in XZ5. In the roots, drought reduced Mg concentrations below levels in their non-droughted counterparts in XZ5 and XZ54 only with no significant difference under any treatment in Tadmor. For Na concentrations in the shoots, for XZ5 and Tadmor, and with the exception 
of Tadmor given the $-\mathrm{K}$ treatment, there were no significant differences in the concentration of this element among the treatments. For XZ54, shoot concentrations tended to be higher in plants given $-\mathrm{K}$ treatments. In addition, plants subjected to drought had higher $\mathrm{Na}$ concentrations than their non-droughted counterparts. In the roots, for all genotypes, the $-\mathrm{K}$ treatment more than doubled the concentrations of $\mathrm{Na}$ above those in the other treatments; however, there were no significant differences among the other treatments. With regard to the $\mathrm{Na}^{+} / \mathrm{K}^{+}$ratios in the shoots, there was no effect of the treatments in XZ5. However, for Tadmor and XZ54, there was a trend for this ratio to be higher in droughted plants than their non-droughted counterparts and for the ratio to be lower in plants given $+\mathrm{K}$ treatments compared to those in $-\mathrm{K}$ treatments. In the roots, this ratio was lower in the plants given the $+\mathrm{K}$ treatments than their $-\mathrm{K}$ counterparts; however, there was no effect of drought treatments.

Table 2. Effect of $\mathrm{K}$ nutrition on shoot and root $\mathrm{Ca}, \mathrm{Na}, \mathrm{K}, \mathrm{Mg}$ concentrations and $\mathrm{Na}^{+} / \mathrm{K}^{+}$ratio of three barley genotypes in response to drought stress.

\begin{tabular}{|c|c|c|c|c|c|c|}
\hline \multirow{2}{*}{ Genotype } & \multirow{2}{*}{ Treatment } & $\mathrm{Ca}$ & $\mathbf{K}$ & Mg & $\mathrm{Na}$ & \multirow{2}{*}{$\begin{array}{c}\mathrm{Na}^{+} / \mathrm{K}^{+} \\
\text {Ratio }\end{array}$} \\
\hline & & \multicolumn{4}{|c|}{$\mathrm{mg} \mathrm{g}^{-1} \mathrm{DW}$} & \\
\hline & & \multicolumn{5}{|c|}{ Shoot mineral concentrations } \\
\hline \multirow{4}{*}{ XZ5 } & $+\mathrm{K}$ & $0.61 \pm 0.13 \mathrm{Cb}$ & $39.16 \pm 0.4 \mathrm{Aa}$ & $0.81 \pm 0.15 \mathrm{Cb}$ & $1.30 \pm 0.17 \mathrm{Ea}$ & $0.03 \mathrm{Fa}$ \\
\hline & $+\mathrm{K}+\mathrm{D}$ & $1.30 \pm 0.25 \mathrm{Aa}$ & $36.83 \pm 0.74 \mathrm{ABa}$ & $0.79 \pm 0.13 \mathrm{Cb}$ & $1.23 \pm 0.20 \mathrm{Ea}$ & $0.03 \mathrm{Fa}$ \\
\hline & $-\mathrm{K}$ & $0.74 \pm 0.04 \mathrm{Cb}$ & $32.17 \pm 1.94 \mathrm{BCab}$ & $1.39 \pm 0.09 \mathrm{Ba}$ & $1.58 \pm 0.31 \mathrm{DEa}$ & $0.05 \mathrm{EFa}$ \\
\hline & $-\mathrm{K}+\mathrm{D}$ & $1.19 \pm 0.17 \mathrm{ABa}$ & $28.03 \pm 1.06 \mathrm{Cb}$ & $1.22 \pm 0.23 \mathrm{Ba}$ & $1.58 \pm 0.05 \mathrm{DEa}$ & $0.06 \mathrm{EFa}$ \\
\hline \multirow{4}{*}{ Tadmor } & $+\mathrm{K}$ & $0.87 \pm 0.20 \mathrm{BCb}$ & $28.86 \pm 4.37 \mathrm{Ca}$ & $0.76 \pm 0.13 \mathrm{CDb}$ & $1.3 \pm 0.24 \mathrm{~Eb}$ & $0.05 \mathrm{EFC}$ \\
\hline & $+\mathrm{K}+\mathrm{D}$ & $1.29 \pm 0.15 \mathrm{Aa}$ & $21.00 \pm 1.57 \mathrm{Fb}$ & $0.43 \pm 0.02 \mathrm{DEbc}$ & $1.72 \pm 0.57 \mathrm{DEb}$ & $0.08 \mathrm{Ebc}$ \\
\hline & $-\mathrm{K}$ & $0.77 \pm 0.06 \mathrm{Cb}$ & $14.57 \pm 1.21 \mathrm{GHc}$ & $1.44 \pm 0.27 \mathrm{Ba}$ & $2.51 \pm 0.30 \mathrm{BCa}$ & $0.17 \mathrm{Ca}$ \\
\hline & $-\mathrm{K}+\mathrm{D}$ & $0.77 \pm 0.21 \mathrm{Cb}$ & $13.46 \pm 1.09 \mathrm{Hc}$ & $0.28 \pm 0.07 \mathrm{Ec}$ & $1.65 \pm 0.33 \mathrm{DEb}$ & $0.12 \mathrm{CDb}$ \\
\hline \multirow[t]{5}{*}{ XZ54 } & $+\mathrm{K}$ & $0.80 \pm 0.13 \mathrm{Cb}$ & $24.52 \pm 1.27 \mathrm{Ea}$ & $0.59 \pm 0.24 \mathrm{CDEbc}$ & $1.81 \pm 0.39 \mathrm{CDEc}$ & $0.07 \mathrm{Ec}$ \\
\hline & $+\mathrm{K}+\mathrm{D}$ & $1.17 \pm 0.27 \mathrm{Aba}$ & $19.58 \pm 2.72 \mathrm{FGb}$ & $0.68 \pm 0.31 \mathrm{CDbc}$ & $2.10 \pm 0.46 \mathrm{BCDbc}$ & $0.11 \mathrm{CDc}$ \\
\hline & $-\mathrm{K}$ & $0.63 \pm 0.04 \mathrm{Cb}$ & $15.25 \pm 1.43 \mathrm{Gbc}$ & $1.84 \pm 0.17 \mathrm{Aa}$ & $2.55 \pm 0.19 \mathrm{Bb}$ & $0.17 \mathrm{Cb}$ \\
\hline & $-\mathrm{K}+\mathrm{D}$ & $0.70 \pm 0.11 \mathrm{Cb}$ & $12.52 \pm 0.97 \mathrm{Hc}$ & $0.81 \pm 0.06 \mathrm{Cb}$ & $4.10 \pm 0.25 \mathrm{Aa}$ & $0.33 \mathrm{Aa}$ \\
\hline & & \multicolumn{5}{|c|}{ Root mineral concentrations } \\
\hline \multirow[t]{4}{*}{ XZ5 } & $+\mathrm{K}$ & $2.40 \pm 0.56 \mathrm{BCDab}$ & $136.59 \pm 17.66 \mathrm{Aa}$ & $3.42 \pm 0.56 \mathrm{ABa}$ & $3.49 \pm 0.67 \mathrm{CDb}$ & $0.03 \mathrm{Db}$ \\
\hline & $+\mathrm{K}+\mathrm{D}$ & $1.34 \pm 0.13 \mathrm{Db}$ & $101.06 \pm 24.51 \mathrm{Bb}$ & $2.41 \pm 0.39 \mathrm{CDb}$ & $2.18 \pm 0.38 \mathrm{Db}$ & $0.02 \mathrm{Db}$ \\
\hline & $-\mathrm{K}$ & $2.53 \pm 0.18 \mathrm{ABCa}$ & $79.00 \pm 5.69 \mathrm{CDbc}$ & $3.79 \pm 0.73 \mathrm{Aa}$ & $8.05 \pm 0.47 \mathrm{Ba}$ & $0.1 \mathrm{Aa}$ \\
\hline & $-\mathrm{K}+\mathrm{D}$ & $1.87 \pm 0.13 \mathrm{Dab}$ & $57.49 \pm 4.02 \mathrm{DEc}$ & $2.29 \pm 0.09 \mathrm{Db}$ & $3.53 \pm 0.62 \mathrm{CDb}$ & $0.06 \mathrm{Cab}$ \\
\hline \multirow[t]{4}{*}{ Tadmor } & $+\mathrm{K}$ & $3.17 \pm 0.98 \mathrm{ABab}$ & $97.16 \pm 21.53 \mathrm{Ba}$ & $3.47 \pm 1.09 \mathrm{ABa}$ & $4.00 \pm 1.25 \mathrm{CDb}$ & $0.04 \mathrm{CDb}$ \\
\hline & $+\mathrm{K}+\mathrm{D}$ & $2.41 \pm 0.77 \mathrm{BCDab}$ & $86.55 \pm 7.36 \mathrm{Cb}$ & $2.69 \pm 0.55 \mathrm{BCDa}$ & $5.04 \pm 0.96 \mathrm{Cb}$ & $0.06 \mathrm{Cb}$ \\
\hline & $-\mathrm{K}$ & $3.33 \pm 0.58 \mathrm{Aa}$ & $75.08 \pm 10.45 \mathrm{CDbc}$ & $3.60 \pm 0.71 \mathrm{ABa}$ & $9.83 \pm 0.43 \mathrm{ABa}$ & $0.13 \mathrm{Aa}$ \\
\hline & $-\mathrm{K}+\mathrm{D}$ & $2.11 \pm 0.79 \mathrm{CDb}$ & $47.34 \pm 10.16 \mathrm{Ec}$ & $2.81 \pm 0.67 \mathrm{BCDa}$ & $4.62 \pm 0.75 \mathrm{Cb}$ & $0.1 \mathrm{Aa}$ \\
\hline \multirow[t]{4}{*}{$X Z 54$} & $+\mathrm{K}$ & $2.55 \pm 0.48 \mathrm{ABCDa}$ & $101.02 \pm 13.04 \mathrm{Ba}$ & $3.37 \pm 0.29 \mathrm{ABCab}$ & $3.64 \pm 0.59 \mathrm{CDb}$ & $0.04 \mathrm{CDb}$ \\
\hline & $+\mathrm{K}+\mathrm{D}$ & $1.78 \pm 0.11 \mathrm{Da}$ & $82.96 \pm 4.96 \mathrm{Cb}$ & $2.25 \pm 0.13 \mathrm{Dc}$ & $3.01 \pm 0.62 \mathrm{CDb}$ & $0.04 \mathrm{CDb}$ \\
\hline & $-\mathrm{K}$ & $2.66 \pm 0.09 \mathrm{ABCa}$ & $78.71 \pm 6.65 \mathrm{CDb}$ & $4.02 \pm 0.64 \mathrm{Aa}$ & $10.62 \pm 2.4 \mathrm{Aa}$ & $0.13 \mathrm{Aa}$ \\
\hline & $-\mathrm{K}+\mathrm{D}$ & $1.63 \pm 0.19 \mathrm{Da}$ & $53.08 \pm 4.11 \mathrm{DEc}$ & $2.74 \pm 0.32 \mathrm{BCDbc}$ & $4.15 \pm 0.68 \mathrm{CDb}$ & $0.08 \mathrm{BCb}$ \\
\hline
\end{tabular}

Different capital and small letter(s) indicate significant differences $(p<0.05)$ among the genotypes and among the 4 treatments within each genotype, respectively. $+K,+K+D,-K$, and $-K+D$, correspond to basic nutrition solution with normal $K$ of $1 \mathrm{mM} \mathrm{K}$ (BNS), BNS $+20 \%$ Polyethylene glycol 6000 (PEG) induced drought stress, BNS without K (K deficiency), and BNS without K + PEG, respectively.

\subsection{Antioxidative Enzyme Activities}

Noticeable differences in antioxidant enzyme activity were seen in response to the $\mathrm{K}$ and drought treatments (Figure 1, Table S4). In the shoots, in general for all enzymes and for all genotypes, plants in the $+\mathrm{K}$ treatment (control) had the lowest activities. Two other trends were also found. Firstly, activities tended to be higher in plants given drought treatments in comparison to their non-droughted counterparts. Secondly, for SOD, APX and malondialdehyde (MDA), activities tended to be higher in $-\mathrm{K}$ and $-\mathrm{K}+\mathrm{D}$ treatments than those where $\mathrm{K}$ was supplied. In the roots, there was little effect of the treatments on 
CAT activity in any of the genotypes. For the remaining enzymes, activities were higher in the $+\mathrm{K}+\mathrm{D}$ treatment than the $+\mathrm{K}$ treatment. Comparing the $-\mathrm{K}+\mathrm{D}$ and $+\mathrm{K}+\mathrm{D}$ treatments, for XZ5, there were no differences between these treatments, for Tadmor, SOD, POD APX activities and MDA contents were lower in the $-\mathrm{K}+\mathrm{D}$ treatment and MDA contents were higher, and for XZ54, only SOD activities and MDA contents were increased in the $-\mathrm{K}+\mathrm{D}$ treatment. The effect of the treatments on the activities of the two ATPases was variable. For both enzymes, the trends in the activities tended to be similar in the roots and shoots of each genotype. For the $\mathrm{Ca}^{2+} / \mathrm{Mg}^{2+}$-ATPase in XZ5, activities of this enzyme were increased by both the drought and $\mathrm{K}$ deprivation treatments in both shoots and roots (Figure S3A,B). In the shoots of Tadmor, the activity of this enzyme was increased under $-\mathrm{K}$ and $-\mathrm{K}+\mathrm{D}$ and under both drought and K deprivation in the roots. For XZ54, there was no effect of the treatments in either roots or shoots. H+-ATPase activity (Figure S3C,D) in the shoots and roots of $X Z 5$ was also increased by $+K+D$ and $-K+D$ treatments. In the shoots of both Tadmor and XZ54, the $-\mathrm{K}$ treatment resulted in the lowest activities, with activities in the other treatments being similar. In the roots of Tadmor, the two drought treatments increased the activity of this enzyme. In XZ54, $\mathrm{H}^{+}$-ATPase activity was increased in the $+\mathrm{K}+\mathrm{D}$ and $-\mathrm{K}$ treatments (Figure S3, Table S5).

\subsection{Proline, Glycine Betaine, Soluble Sugars and Proteins Contents}

In general, drought increased the concentrations of proline in the shoots and GB in shoots and roots of all genotypes (Figure 2, Table S6); for XZ5, the shoot concentrations of these compounds were also increased in the $-\mathrm{K}$ treatment compared to the $+\mathrm{K}$ control. Concentrations of proline in the roots of XZ5 and Tadmor were increased by both the drought and the $-\mathrm{K}$ treatments. For XZ54, only the $-\mathrm{K}$ treatment increased the concentration of this compound. With respect to both soluble sugars and proteins in the shoots, with the exception of soluble sugars in XZ54, both the drought and K deprivation treatments increased concentrations of these compounds above concentrations in the $+\mathrm{K}$ control; in $\mathrm{XZ54}$, soluble sugar concentrations were increased in the $+\mathrm{K}+\mathrm{D}$ treatment but reduced in the other two treatments. In the roots, the effect of the treatments on these two groups of compounds was variable among the genotypes. For soluble sugars, concentrations of these compounds were increased by the two drought treatments in XZ5, increased by all three treatments in Tadmor, and for XZ54, sugars were decreased by the two -K treatments. For concentrations of soluble proteins in the roots, the treatments had little effect with increases or decreases compared to the control being small.

\subsection{Secondary Metabolism-Related Enzyme Activities}

The activities of enzymes related to secondary metabolism in shoot and roots are presented in Figure 3 and Table S7. In the shoots, the two drought treatments increased the activities of all enzymes. Also, in general, the activities of these enzymes were also increased by the $-\mathrm{K}$ treatment. Activities of these enzymes in the roots were variable among genotypes, treatments and enzymes. For shikimate dehydrogenase (SKDH) in the roots of XZ5 and Tadmor, the drought treatments increased activities; the $-\mathrm{K}$ treatment also increased SKDH activity in XZ5, but reduced it in Tadmor. In XZ54, the $+\mathrm{K}+\mathrm{D}$ treatment resulted in reduced SKDH activity. For cinnamyl alcohol dehydrogenase (CAD), in most incidences, the activities of this enzyme were reduced below control levels by the three treatments. For polyphenol peroxidase (PPO) in the roots, there were little effects of the treatments, and differences from the controls were small. Lastly, for phenylalanine ammonialyase (PAL), the drought treatments tended to increase activities in XZ5 and Tadmor; the $-\mathrm{K}$ treatment also resulted in increased activity in XZ5. For XZ54, PAL activity was increased above control levels in the $+\mathrm{K}+\mathrm{D}$ treatment and reduced in the $-\mathrm{K}+\mathrm{D}$ treatment. 


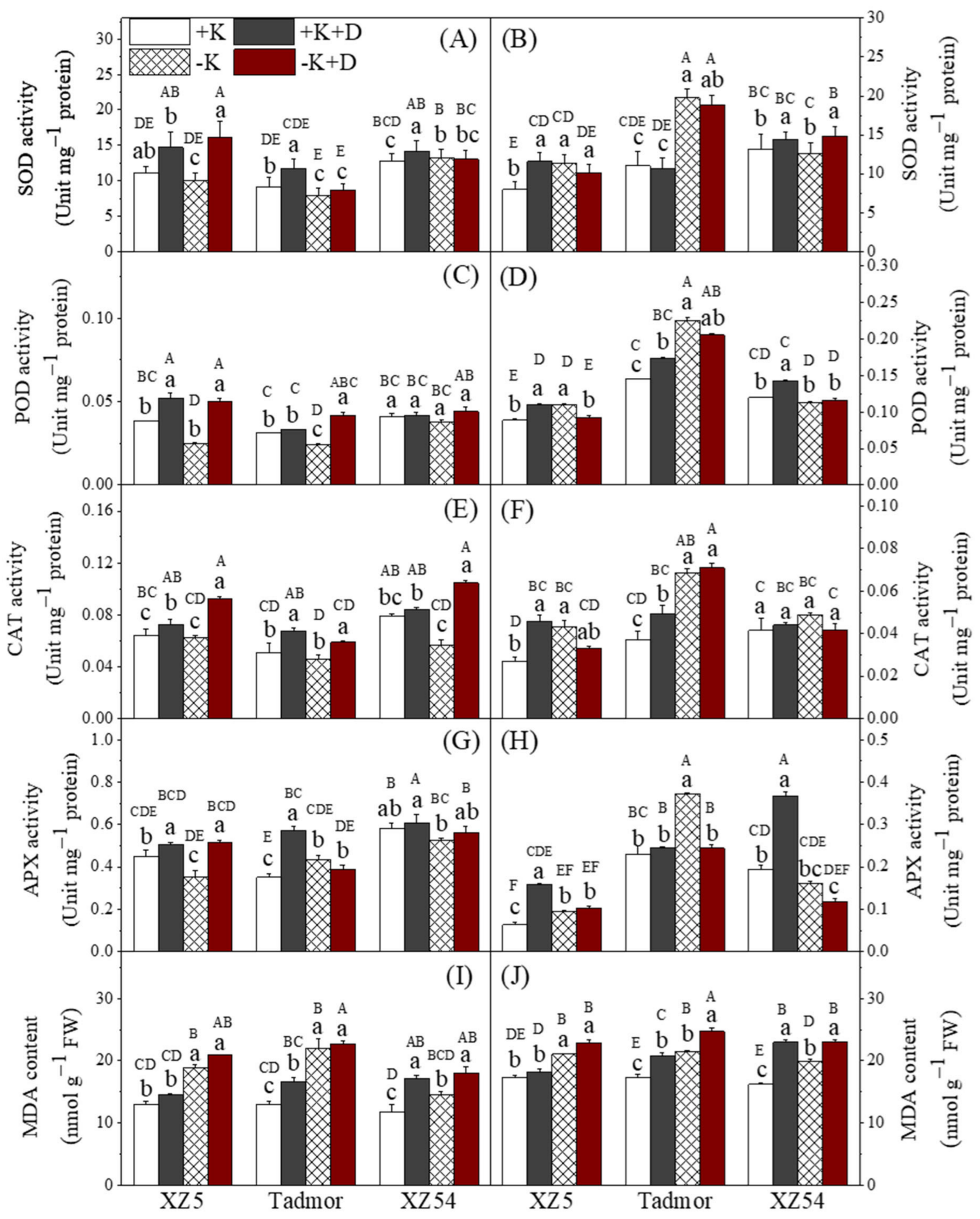

Figure 1. Effect of alone and combined stress of drought and $\mathrm{K}$ deprivation on antioxidant enzyme activities of SOD (A,B), POD (C,D), CAT (E,F), APX (G,H) and MDA contents (I,J) in leaves (left panel) and roots (right panel) of three barley genotypes. Different capital and small letter(s) indicate significant differences $(p<0.05)$ among the genotypes and among the 4 treatments within each genotype, respectively. $+\mathrm{K}$ (control), $+\mathrm{K}+\mathrm{D},-\mathrm{K}$, and $-\mathrm{K}+\mathrm{D}$, correspond to basic nutrition solution with normal K of $1 \mathrm{mM} \mathrm{K}$ (BNS), BNS + 20\% polyethylene glycol 6000 (PEG), BNS without K (K deprivation), and BNS without $\mathrm{K}+\mathrm{PEG}$, respectively. Error bars represent standard deviations $(n=3)$. 


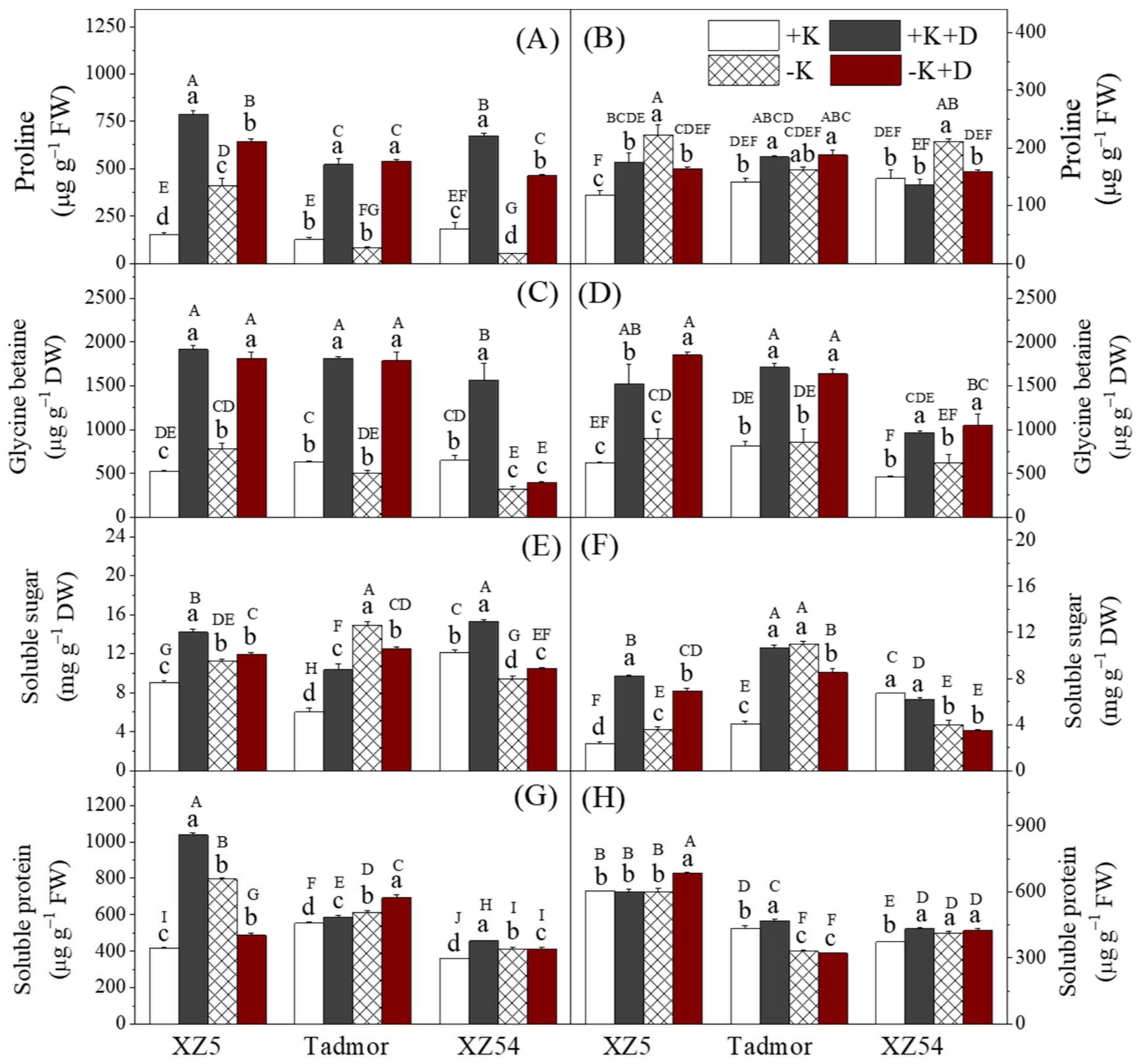

Figure 2. Effect of alone and combined stress of drought and $\mathrm{K}$ deprivation on proline, glycine betaine, soluble sugar and soluble protein contents in leaves $(\mathbf{A}, \mathbf{C}, \mathbf{E}, \mathbf{G})$ and roots $(\mathbf{B}, \mathbf{D}, \mathbf{F}, \mathbf{H})$ of three barley genotypes. Different capital and small letter(s) indicate significant differences $(p<0.05)$ among the genotypes and among the 4 treatments within each genotype, respectively. $+\mathrm{K},+\mathrm{K}+\mathrm{D},-\mathrm{K}$, and $-\mathrm{K}+\mathrm{D}$, correspond to basic nutrition solution with normal $\mathrm{K}$ of $1 \mathrm{mM} \mathrm{K}$ (BNS), BNS + $20 \%$ polyethylene glycol 6000 (PEG), BNS without K (K deprivation), and BNS without K + PEG, respectively. Error bars represent standard deviations $(n=3)$. 


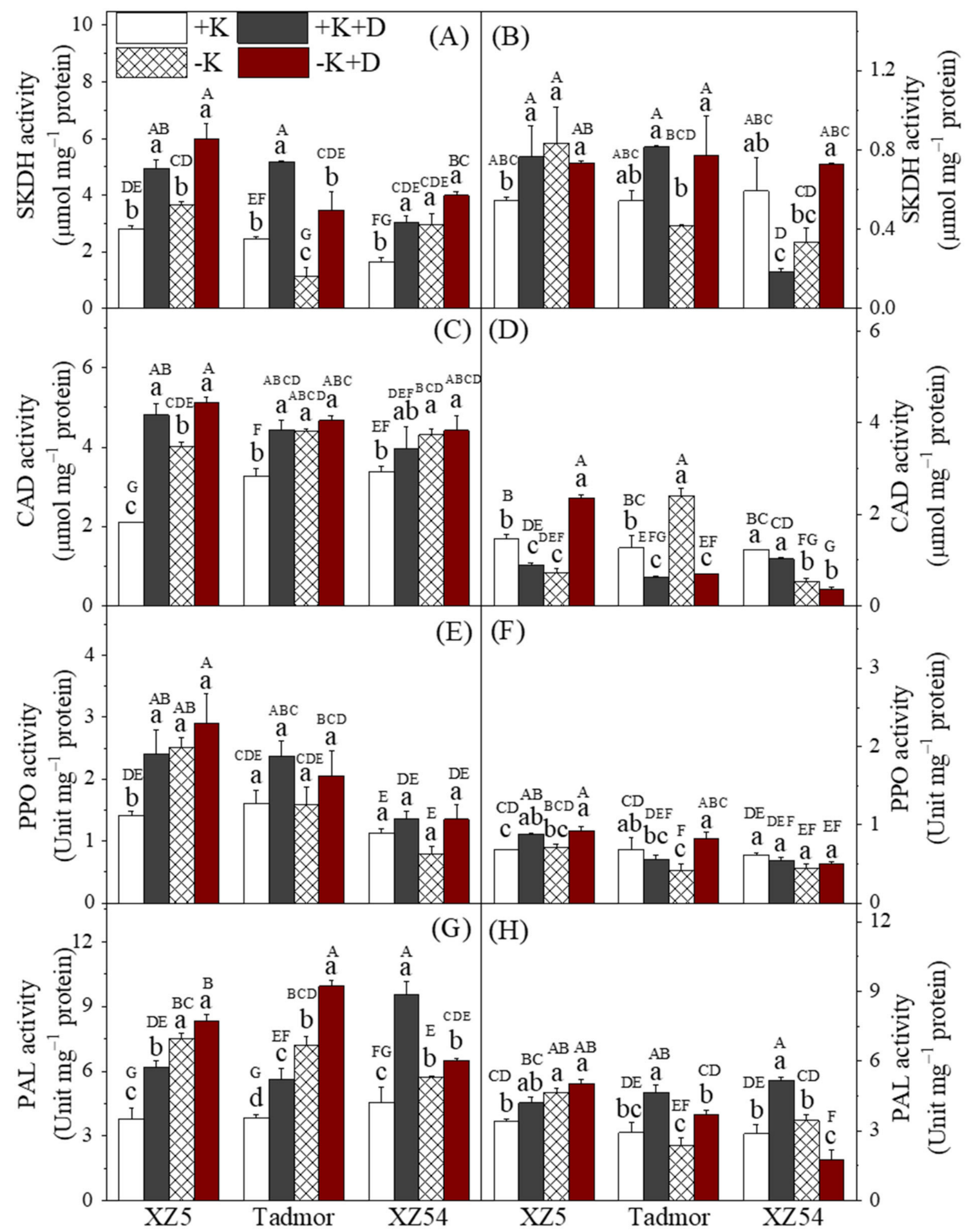

Figure 3. Effect of alone and combined stress of drought and $\mathrm{K}+$ deprivation on secondary metabolism-related enzymes PAL, PPO, CAD and SKDH activities in leaves $(\mathbf{A}, \mathbf{C}, \mathbf{E}, \mathbf{G})$ and roots $(\mathbf{B}, \mathbf{D}, \mathbf{F}, \mathbf{H})$ of three barley genotypes. Different capital and small letter(s) indicate significant differences $(p<0.05)$ among the genotypes and among the 4 treatments within each genotype, respectively. $+\mathrm{K},+\mathrm{K}+\mathrm{D},-\mathrm{K}$, and $-\mathrm{K}+\mathrm{D}$, correspond to basic nutrition solution with normal $\mathrm{K}$ of $1 \mathrm{mM} \mathrm{K}$ (BNS), BNS + 20\% Polyethylene glycol 6000 (PEG), BNS without K (K deprivation), and BNS without K + PEG, respectively. Error bars represent standard deviations $(n=3)$. 


\subsection{Secondary Metabolites}

The activity of chitinase in the shoots (Figure 4A) was increased in XZ5 and Tadmor by all treatments. For XZ54, the drought treatments also increased the activity of this enzyme in the shoots; however, the activity was not significantly different from the control in the $-\mathrm{K}$ treatment. In the roots, with the exception of plants of XZ54 given the $-\mathrm{K}+\mathrm{D}$ treatment, chitinase activity was higher in all genotypes and treatments (Figure $4 \mathrm{~B}$ ); for plants of XZ54 given the $-\mathrm{K}+\mathrm{D}$ treatment, chitinase activity was lower than the controls. In the shoots, flavonoid contents were greatly increased by the drought and $\mathrm{K}$ deprivation treatments compared to the controls (Figure 4C). In the roots, flavonoid contents were lower than in the shoots and differences from the control were small (Figure 4D). The $+\mathrm{K}+\mathrm{D}$ treatment increased the concentration of these compounds compared to the control in all three genotypes, the $-\mathrm{K}$ treatment only increased flavonoids in $\mathrm{XZ5}$, and the $-\mathrm{K}+\mathrm{D}$ treatment increased flavonoid contents in XZ5 and Tadmor, but reduced them in XZ54. Total phenolic contents in shoots were increased above control levels by the two drought treatments (Figure $4 \mathrm{E}$ ). The $-\mathrm{K}$ treatment had variable effects on the three genotypes, having no effect on concentrations in XZ5, increasing them in Tadmor and reducing them in XZ54. In the roots (Figure $4 \mathrm{~F}$ ), both drought and $\mathrm{K}$ deprivation increased TP contents, with a possible interaction occurring between drought and $\mathrm{K}$ deprivation in XZ5 and Tadmor. Callose contents are presented in Figure $4 \mathrm{G}$ and H. In the shoots, the two K deprivation treatments $(-\mathrm{K}$ and $-\mathrm{K}+\mathrm{D})$ increased callose concentrations in all three genotypes; the $+\mathrm{K}+\mathrm{D}$ treatment increased concentrations in XZ5 and XZ54 but not in Tadmor. In the roots, callose concentrations were higher than the shoots. The two drought treatments increased the contents of this compound in all three genotypes; the $-\mathrm{K}$ treatment had little effect on callose concentrations (Figure 4, Table S8).

\subsection{Gene Expression Associated with ROS Scavenging and Secondary Metabolism}

To understand the changes at the molecular level caused by drought and K deprivation, alone or in combination, on antioxidant enzyme-associated genes, the transcript levels of CZSOD, APX1, CAT1 and CAT2 genes were investigated (Figure 5, Table S9). For CZSOD, in $\mathrm{XZ} 5$, only the $-\mathrm{K}+\mathrm{D}$ treatment showed a difference from the control (a 1.7-fold increase); for the other two genotypes the two $-\mathrm{K}$ treatments reduced expression, while in roots, for $\mathrm{XZ5}$ and Tadmor, both the $-\mathrm{K}$ and drought treatments increased expression; there were no significant differences from the control in XZ54 (Figure 5A,B). In the shoots, for XZ5 and Tadmor, the expression of APX1 was increased by the two drought treatments (Figure 5C), whereas the shoots of XZ54 exhibited a contrasting trend. In the roots, both drought and $-\mathrm{K}$ treatments increased expression of APX1 (Figure $5 \mathrm{D}$ ) in XZ5 whereas, for the other two genotypes, only the drought treatments displayed increases in expression above the controls. The shoot and root CAT1 transcript levels of the three genotypes are presented in Figure 5E,F. In the shoots, for XZ5, only the $-\mathrm{K}+\mathrm{D}$ treatment increased transcript levels; the other treatments had no effect. For the other two genotypes, the $+\mathrm{K}+\mathrm{D}$ treatment greatly increased expression; the two K deprivation treatments tended to reduce transcript levels. In the roots, the two drought treatments greatly increased expression of CAT1 in XZ5 and Tadmor; in XZ54, the $-\mathrm{K}$ and $+\mathrm{K}+\mathrm{D}$ treatments increased expression. For transcript levels of CAT2 in the shoots, for XZ5, the two drought treatments increased expression whereas the $-\mathrm{K}$ treatment reduced it. For Tadmor and XZ54, expression of CAT2 was reduced by both the drought and $\mathrm{K}$ deprivation treatments. In the roots, there was a trend for both drought and K deprivation to increase transcript levels (Figure $5 \mathrm{H}$ ). 


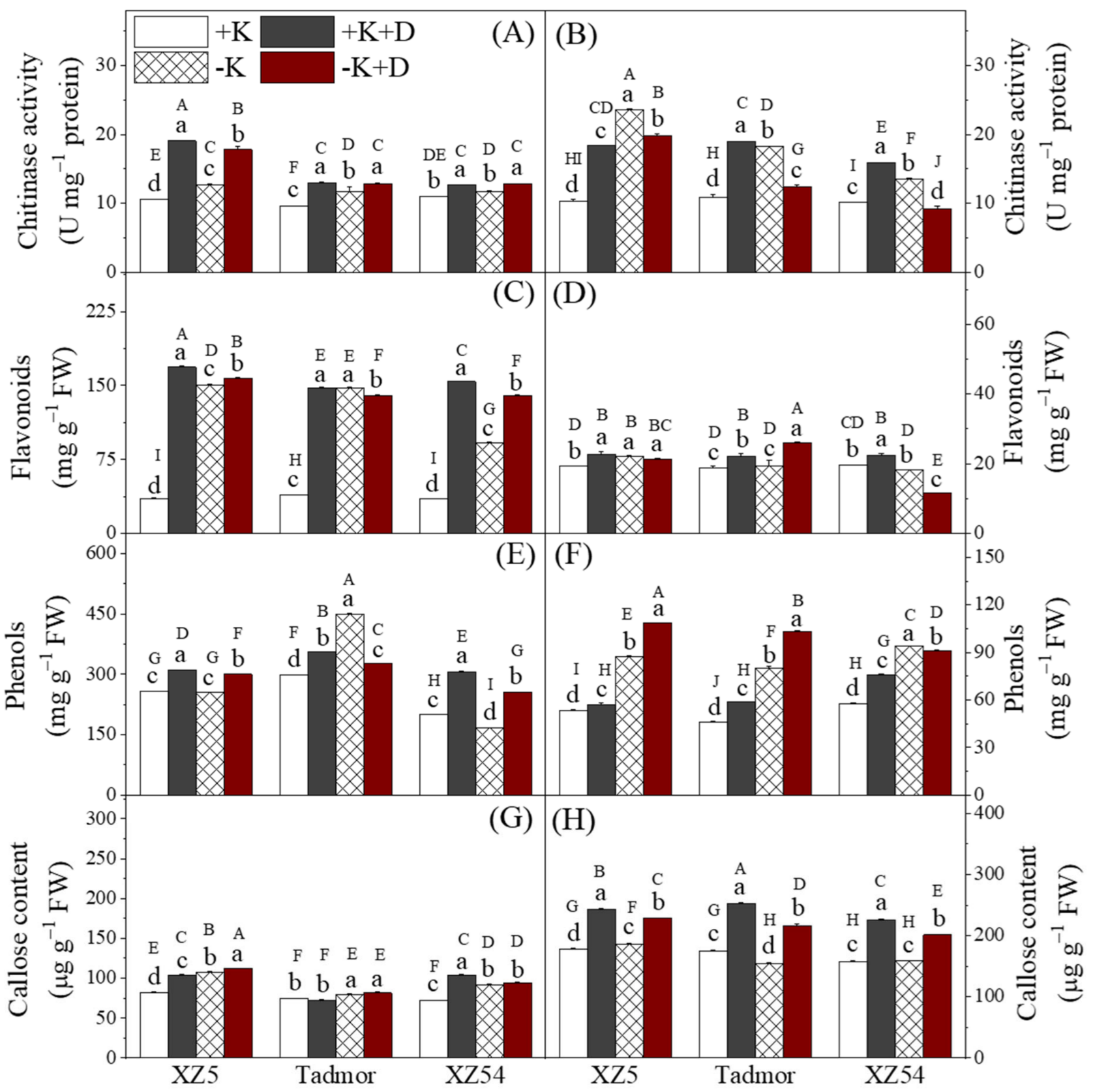

Figure 4. Effect of alone and combined stress of drought and $\mathrm{K}$ deprivation on secondary metabolites callose, phenol, flavonoids and chitinase activity in leaves $(\mathbf{A}, \mathbf{C}, \mathbf{E}, \mathbf{G})$ and roots $(\mathbf{B}, \mathbf{D}, \mathbf{F}, \mathbf{H})$ of three barley genotypes. Different capital and small letter(s) indicate significant differences $(p<0.05)$ among the genotypes and among the 4 treatments within each genotype, respectively. $+\mathrm{K},+\mathrm{K}+\mathrm{D},-\mathrm{K}$, and $-\mathrm{K}+\mathrm{D}$, correspond to basic nutrition solution with normal $\mathrm{K}$ of $1 \mathrm{mM} \mathrm{K}$ (BNS), BNS $+20 \%$ polyethylene glycol 6000 (PEG), BNS without K (K deprivation), and BNS without K + PEG, respectively. Error bars represent standard deviations $(n=3)$. 


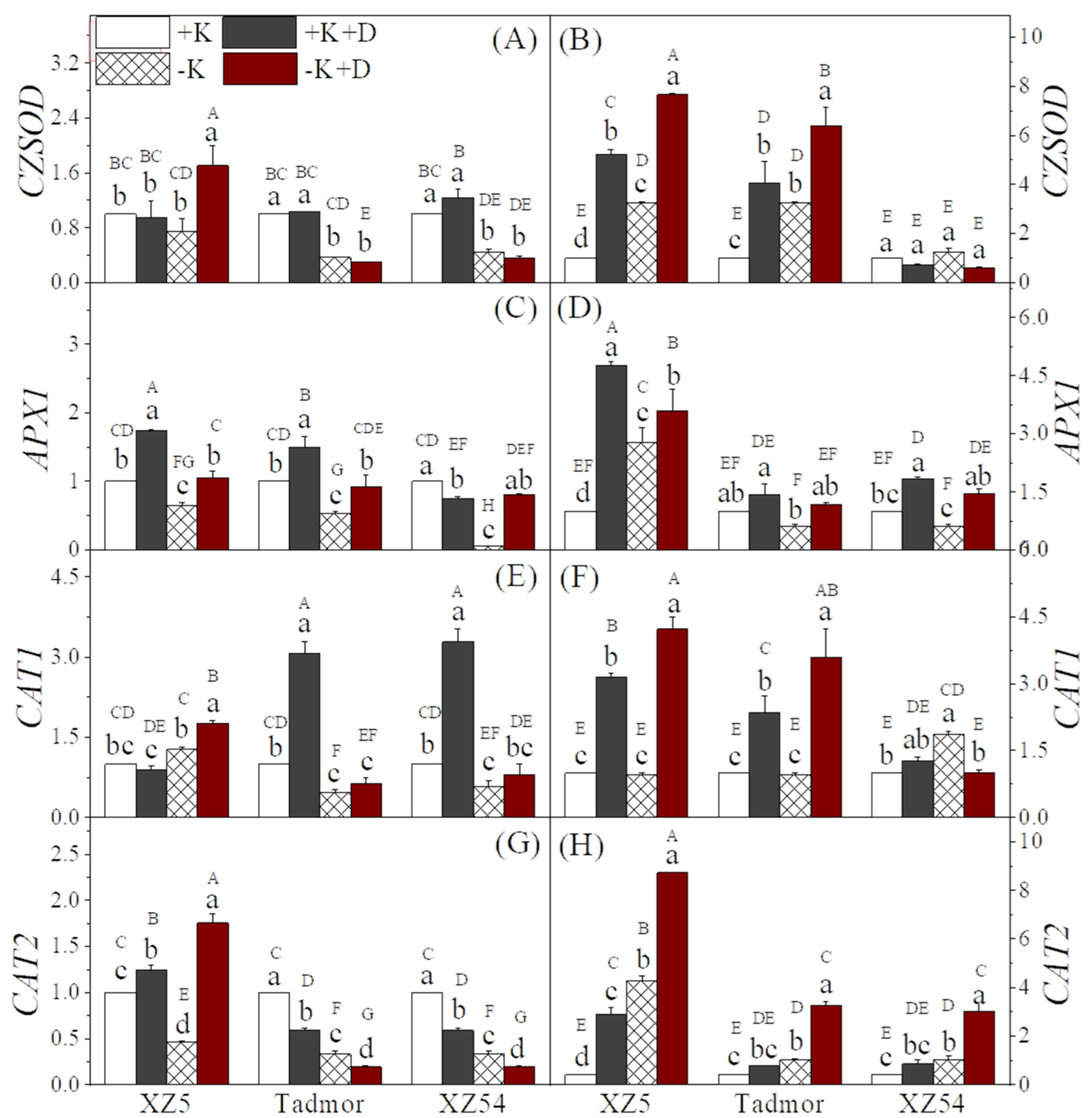

Figure 5. Antioxidant enzyme related gene expression analyzed by qRT-PCR in Tibetan wild barley XZ5 and XZ54, and cv. Tadmor. Barley plants were exposed to alone and combined stresses of drought and K+ deprivation on CZSOD, APX1, CAT1 and CAT2 gene expression study in leaves $(\mathbf{A}, \mathbf{C}, \mathbf{E}, \mathbf{G})$ and roots $(\mathbf{B}, \mathbf{D}, \mathbf{F}, \mathbf{H})$ of three barley genotypes, $\mathrm{XZ5}$, Tadmor and XZ54. Different capital and small letter(s) indicate significant differences $(p<0.05)$ among the genotypes and among the 4 treatments within each genotype, respectively. Error bars represent standard deviations $(n=4)++\mathrm{K},+\mathrm{K}+\mathrm{D},-\mathrm{K}$, and $-\mathrm{K}+\mathrm{D}$, correspond to basic nutrition solution with normal K of $1 \mathrm{mM} \mathrm{K}$ (BNS), BNS + 20\% Polyethylene glycol 6000 (PEG), BNS without $\mathrm{K}$ (K deprivation), and BNS without $\mathrm{K}+\mathrm{PEG}$, respectively.

To gain a better understanding at the molecular level of changes in secondary metabolism, the transcript levels of the PAL, PPO, CAD and SKDH genes were studied (Figure 6, Table S10). In general, for all enzymes, expression varied with both treatment and genotype and their transcript levels were in agreement with physiological data. Shoots of XZ5 displayed increased expression of PAL under both drought treatments (Figure 6A), while in Tadmor, the two K deprivation treatments reduced its transcript levels. In the roots (Figure 6B) of the two drought tolerant genotypes, the expression of PAL was increased by the two K deprivation treatments, whereas in XZ54, expression was only enhanced under $-\mathrm{K}$. A significant increase in PPO expression in XZ5 shoots was observed in the two drought treatments (Figure 6C). In Tadmor, only $+\mathrm{K}+\mathrm{D}$ increased the expression of this enzyme, and the other two treatments reduced expression. In XZ54, expression was increased in the $-\mathrm{K}+\mathrm{D}$ treatment but decreased in the 
other two. Moreover, the two K deprivation treatments increased expression of PPO in XZ5 and Tadmor roots, but there were no significant differences among the treatments in XZ54 (Figure 6D). The expression of CAD in the shoots was increased by the two drought treatments in XZ5 and XZ54 (Figure $6 \mathrm{E}$ ), but only by the $+\mathrm{K}+\mathrm{D}$ treatment in Tadmor. In the roots, for the two drought tolerant genotypes, there was a trend for all treatments to increase the expression of this gene; however, these effects were greater in Tadmor (Figure 6F). Figure 6 G,H present the changes in expression of SKDH. The expression of this gene was increased by the two drought treatments in all genotypes; the $-\mathrm{K}$ treatment also increased expression in shoots of XZ5 and XZ54, whereas the roots of two drought tolerant genotypes showed increased expression of this gene under both drought treatments. Additionally, XZ5 roots exhibited increased levels of transcripts under $-\mathrm{K}$. In XZ54, only the $+\mathrm{K}+\mathrm{D}$ treatment increased SKDH expression.

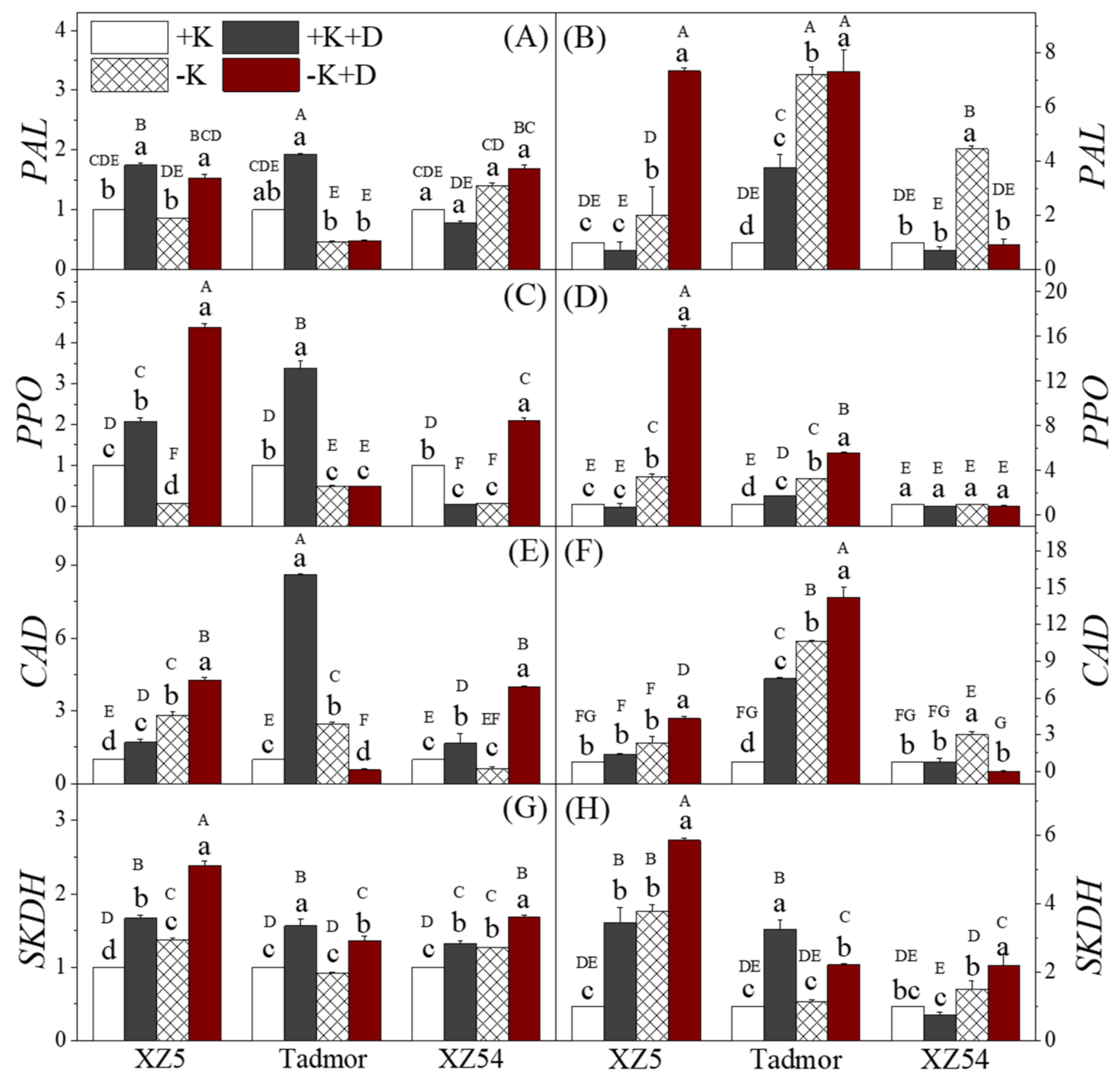

Figure 6. Secondary metabolism related gene expression analyzed by qRT-PCR in Tibetan wild barley XZ5 and XZ54, and cv. Tadmor. Barley plants were exposed to alone and combined stresses of drought and K deprivation, PAL, PPO, CAD and SKDH gene expression were studied in leaves $(\mathbf{A}, \mathbf{C}, \mathbf{E}, \mathbf{G})$ and roots $(\mathbf{B}, \mathbf{D}, \mathbf{F}, \mathbf{H})$ of three barley genotypes. Different capital and small letter(s) indicate significant differences $(p<0.05)$ among the genotypes and among the 4 treatments within each genotype, respectively. Error bars represent standard deviations $(n=4) .+\mathrm{K},+\mathrm{K}+\mathrm{D},-\mathrm{K}$, and $-\mathrm{K}+\mathrm{D}$, correspond to basic nutrition solution with normal K of $1 \mathrm{mM} \mathrm{K}$ (BNS), BNS $+20 \%$ Polyethylene glycol 6000 (PEG), BNS without K (K deprivation), and BNS without $\mathrm{K}+\mathrm{PEG}$, respectively. 


\section{Discussion}

Tibetan wild barley constitutes an important genetic resource and contributes to pastoral production particularly in semi-arid regions because of its drought tolerance. In a previous study, Zhao et al. [16] reported that the Tibetan wild-barley genotype, XZ5, grows well under drought conditions; this could also be observed in our study. The severity of drought stress symptoms (reduction in biomass, shoot heights, root lengths, wilting and the appearance of chlorotic patches) were less in XZ5 compared to Tadmor and indicate the potential of wild barley as a source for drought tolerant alleles that can be used in the breeding of cultivated barley. In addition, XZ54 showed greater relative reductions in growth due to the $\mathrm{K}$ deprivation treatments suggesting that drought tolerance is at least in part associated with the homeostasis of this element (Table 1). Drought stress is well documented as reducing photosynthetic characteristics, shortening the duration of photosynthesis and promoting leaf senescence. A decrease in $P n$ limits expansion of the assimilation area of vegetative organs, and a notable reduction has been demonstrated in $P n$ during several investigations of drought stress in different plant species [19] as was found in our results. A large reduction in Gs and Tr is a consequence of stomatal closure in response to drought and is an important stress avoidance mechanism in plants [20]; reductions in these parameters were also found in our study (Figure S2). A greater decrease in Fv / Fm was observed in XZ54 in the two drought stress treatments as compared to XZ5 and Tadmor, which suggests a possible inhibition of PSII photochemistry in XZ54 (Figure S1). A higher protective capacity for PSII is an important tolerance mechanism for barley exposed to drought [12]. K can play a role in rescuing photosynthetic activities [13] and in this study, the two K deprivation treatments reduced certain photosynthetic parameters compared to plants given sufficient $\mathrm{K}$.

Nutrient acquisition by roots and their transport to shoots is significantly affected by drought stress which restricts $\mathrm{K}$ diffusion in the soil towards the roots, thereby limiting K absorption $[13,17]$. In our study, there were significant genotypic differences in shoot $\mathrm{Na}^{+}$and $\mathrm{K}^{+}$concentrations in response to drought stress and $\mathrm{K}$ deprivation in the barley genotypes (Table 2). Potassium, being highly mobile, is easily translocated at both the cellular and plant levels and could translocate from older to younger leaves under K deficiency in genotypes that are tolerant of low K concentrations [21]. Our results indicate that tolerance to drought stress in XZ5 was associated with higher K uptake and translocation and a lower $\mathrm{Na}^{+} / \mathrm{K}^{+}$ratio (Table 2). For XZ54 and Tadmor, their decreased photosynthetic capacity could also be attributed to an increased leaf $\mathrm{Na}^{+} / \mathrm{K}^{+}$ratio, as has been shown by James et al. [22]. The genotypes showed clear differences in their abilities to take up $\mathrm{K}$ with the concentrations in shoots being in the same order as their drought tolerance. This suggests that XZ5 is a good source of genes for $\mathrm{K}$ uptake and also supports the contention of a link between $\mathrm{K}$ uptake and drought tolerance. Another clear trend was the enhanced concentration of $\mathrm{Ca}^{2+}$ in the shoots of all genotypes given the drought stress treatments, particularly in XZ5. This suggests a role for $\mathrm{Ca}^{2+}$ in drought stress signaling in XZ5, and accords with a previous study conducted by Tuteja and Mahajan [23], showing that cellular $\mathrm{Ca}^{2+}$ regulates gene expression and is also crucial for plant defense against various stresses.

Studies on the interaction between drought and magnesium are relatively rare but a few have found reductions in leaf $\mathrm{Mg}$ contents due to drought [24]. In this study, drought per se did not affect leaf $\mathrm{Mg}$ concentrations. However, in the shoots, of Tadmor and XZ54, the combined effect of the $-\mathrm{K}$ and $+\mathrm{D}$ treatments reduced $\mathrm{Mg}$ concentrations, which is a reflection of greater interaction between these two treatments. In the roots, drought reduced $\mathrm{Mg}$ concentrations in XZ5 and XZ54; a similar trend was seen in Tadmor. Drought increases ROS production by chloroplasts, peroxisomes and mitochondria and this could be further enhanced in K-deficient plants $[8,25]$. K deficiency induces ABA accumulation that in turn induces the activity of nicotinamide adenine dinucleotide phosphate (NADPH)-dependent oxidases and the formation of NADPH-dependent ROS [11]. To counteract the resulting oxidative damage, plants have evolved a complex mechanism to induce antioxidative enzymes, including SOD, POD, APX and CAT [5,10], and increased activities of these 
enzymes in response to drought were found in all genotypes in this study (Figure 1). K deprivation also increased the activities of these antioxidant enzymes with the greatest effect in XZ5 and the least in XZ54; again, suggesting that adequate K nutrition may play a role in mediating drought tolerance. PPOs are also associated with a plant's response to biotic and abiotic stresses including the response to water deficit catalyzing the reduction of $\mathrm{H}_{2} \mathrm{O}_{2}$ [25]. In our study, we also found a significant induction of PPO activity in the leaves of XZ5 and Tadmor under stress, the drought tolerant genotypes, but no changes in XZ54 (Figure 3).

Genes encoding the antioxidant enzymes are differentially influenced by abiotic stresses in barley roots and leaves $[1,10]$. Drought increased expression of all four genes in the roots of XZ5, and CZSOD and CAT1 in Tadmor, suggesting that these droughttolerant genotypes are better able to increase gene expression in response to drought stress (Figure 5). In addition to the enzymes mentioned above, plants contain non-enzymic means of scavenging ROS. Flavonoids arising from the shikimate pathway are associated with defense mechanisms [26], and are able to scavenge ROS. Flavonoid contents were increased by drought and $\mathrm{K}$ deprivation in the shoots of all three genotypes; however, there was little difference among them, neither were there marked differences among the genotypes and treatments in the roots. In addition to flavonoids, other phenolic compounds also play a role in the alleviation of oxidative stress and the detoxification of ROS [15]. Our study showed an increase in phenolic contents in the leaves and roots in response to drought with XZ5 and Tadmor having higher levels than XZ54 in the shoots (Figure 4). Most natural phenolic compounds in plants are derived from trans-cinnamic acid due to the action of PAL and correlations have been found between PAL activity, accumulation of phenolics and drought tolerance [27]. PAL activity was elevated in the leaves in response to both the drought and $\mathrm{K}$ deprivation treatments with, in general, XZ5 and Tadmor showing the greatest elevations; PAL activity in the roots of XZ5 tended to be higher than the other two genotypes, particularly in response to the drought treatments (Figure 3). Despite these changes in PAL activity, no obvious association with phenolic contents was found. MDA contents are often used as an indicator of the extent of lipid peroxidation resulting from oxidative stress [9]; lower MDA contents indicate reduced lipid peroxidation. In our study, the combined effects of drought and $-\mathrm{K}$ treatments are reflected by the difference in the levels of lipid peroxidation in both analyzed tissues (Figure 1).

Changes in the activities of $\mathrm{Ca}^{2+}-\mathrm{Mg}^{2+}$-ATPase in chloroplasts are crucial for plant functioning under stress and have reportedly been involved in drought tolerance in sweet potatoes [28]. The current study showed that $-\mathrm{K}+\mathrm{D}$ treatment increased the activity of this enzyme in the roots of both drought-tolerant genotypes as well as increased the activity, particularly in the leaves of XZ5 (Figure S3). $\mathrm{H}^{+}$-ATPase is associated with a broad range of physiological processes including cell wall acidification, cytoplasmic $\mathrm{pH}$ regulation, and the provision of proton motive force for secondary active transport and $\mathrm{K}$ is absorbed by means of proton-mediated transport systems [29]. The activity of this enzyme being greatest in the leaves and roots of XZ5 could explain both its higher K uptake and drought tolerance of the three genotypes tested. Increased accumulation of compatible solutes has been indicated as an adaptive response to abiotic stress [8,30]. Proline is a well-known osmoprotectant in plants, and accumulates under saline conditions and functions as a protein stabilizer, a hydroxyl radical scavenger, a source of carbon and nitrogen and a cell membrane stabilizer [7]. In the present study, proline was higher in the roots of XZ5 and Tadmor than those of $X Z 54$ subjected to $+K+D$ and $-K+D$ treatments potentially improving the hydration status of XZ5 and Tadmor. In addition, concentrations of soluble sugars were reduced by the two treatments in the roots of XZ54 but increased in the drought-tolerant genotypes (i.e., XZ5 and Tadmor). Lower osmotic potentials could increase the turgor pressure leading to higher water potentials in XZ5 and Tadmor than in XZ54, which also indicate they have higher water-holding capacities. GB has also been shown to have a beneficial role in plant species under abiotic stress, and accumulation of GB can improve their capacity for osmotic adjustment under drought stress [31] as was found in this study 
and accumulation was higher in the two drought tolerant genotypes than in XZ54. Soluble protein contents increased in tissues under all stresses but were higher in the two drought tolerant types. In the current study, protein contents were most increased in XZ5 and Tadmor suggesting a role in drought tolerance (Figure 2).

Enhanced CAD activity results in an increase in the synthesis of cinnamyl alcohols and is a specific marker of lignification. Drought treatments have been shown to increase CAD expression in Linum usitatissimum L. [32] and Cucumis melo L. [33], and these authors suggest that enhanced lignification improves the mechanical strength of root cells and helps alleviate osmotic stresses. In our experiment, CAD activity was induced by both drought and $\mathrm{K}$ deprivation in the shoots, but differences between genotypes were small; activities in the roots were low. The activity of SKDH, an enzyme involved in the production of aromatic amino acids, precursors of lignin, was also increased by the drought and the $\mathrm{K}$ deprivation treatments (Figure 6). This was particularly noticeable in XZ5 and Tadmor, and this enzyme may contribute to drought tolerance in general and to the better growth of the two tolerant genotypes. In addition to a role in plant development, chitinases have a participation in general stress response. Accordingly, a greater tolerance to drought was found in transgenic plants expressing chitinase genes [34]. In this study, XZ5 showed the greatest increases in chitinase activity in the shoots and roots in response to the drought treatments, suggesting that tolerance of drought in this genotype may be mediated by chitinase. Callose takes part in several important processes associated with plant development and is involved in responses to multiple biotic and abiotic factors [35]. Our results showed that both drought and $\mathrm{K}$ deprivation increased callose contents in the shoots with increases being greater in the wild barley genotypes; the drought treatments also increased callose contents in the roots of all genotypes but there was little difference among the genotypes.

\section{Materials and Methods}

\subsection{Plant Materials, Growth Conditions and Physiological Parameters}

Greenhouse hydroponic experiments were conducted employing two Tibetan wild barley genotypes XZ5 (drought-tolerant) and XZ54 (drought-sensitive) (Hordeum vulgare L. ssp. spontaneum) screened and identified in our previous study [16], and a drought-tolerant cv. Tadmor. Seeds were surface sterilized with $2 \% \mathrm{H}_{2} \mathrm{O}_{2}$ for $30 \mathrm{~min}$, rinsed thoroughly with distilled water, and then germinated on sterilized moist quartz sand in germination trays in a growth chamber $\left(22 / 18{ }^{\circ} \mathrm{C}\right.$ day/night and $80 \%$ relative humidity $\left.(\mathrm{RH})\right)$. Uniform, healthy, 7-day-old seedlings were transplanted into $5.5 \mathrm{~L}$ containers filled with $5 \mathrm{~L}$ basal nutrient solution (BNS). The composition of BNS was as follows $\left(\mathrm{mg} \mathrm{L}^{-1}\right)$ : $\mathrm{KCl} 74.5$, $\mathrm{Ca}\left(\mathrm{NO}_{3}\right) 2.4 \mathrm{H} 2 \mathrm{O} 236, \mathrm{MgSO}_{4} .7 \mathrm{H}_{2} \mathrm{O} 98.4, \mathrm{NH}_{4} \mathrm{H}_{2} \mathrm{PO} 423, \mathrm{H}_{3} \mathrm{BO}_{3} 0.185, \mathrm{MnCl}_{2} .4 \mathrm{H}_{2} \mathrm{O} 0.099$, $\left(\mathrm{NH}_{4}\right)_{6} \mathrm{Mo}_{7} \mathrm{O}_{24} 1.236, \mathrm{ZnSO}_{4} .7 \mathrm{H}_{2} \mathrm{O} 0.115, \mathrm{CuSO}_{4} .5 \mathrm{H}_{2} \mathrm{O} 0.05, \mathrm{Fe}(\mathrm{III})$-EDTA 8.42 [36]. The $\mathrm{pH}$ of the BNS was adjusted to $5.8 \pm 0.1$ with $\mathrm{NaOH}$ or $\mathrm{HCl}$. The solution was continuously aerated with pumps and renewed every 4 days. After 7 days of acclimatization, seedlings were deprived of $\mathrm{K}$ (excluding $\mathrm{KCl}$ ) for 5 days and then each genotype was divided into four different treatments: seedlings grown in BNS with normal K nutrition $(1 \mathrm{mM})(+\mathrm{K}$, control); BNS + 20\% PEG $6000(+\mathrm{K}+\mathrm{D})$; BNS without $\mathrm{K}(-\mathrm{K})$; and -K + 20\% PEG 6000 ($\mathrm{K}+\mathrm{D})$. The experiment was laid out as a completely randomized design with five replicates (in total 60 pots; each having 14 seedlings). After 7 days of PEG treatment, plants were sampled for the measurement of root length, shoot height and fresh weight. Fresh root and leaf samples were immediately frozen in liquid nitrogen and stored at $-80^{\circ} \mathrm{C}$ for further analyses. The remainder was dried for $3 \mathrm{~h}$ at $105^{\circ} \mathrm{C}$ and then for another $24 \mathrm{~h}$ at $80 \pm 1.5^{\circ} \mathrm{C}$ to a constant dry weight for the measurement of dry biomass and elemental composition.

\subsection{Chlorophyll and Photosynthetic Attributes}

The second fully-expanded leaves (three plants per pot) of 26 days old plants were selected to measure relative chlorophyll contents using a chlorophyll meter (SPAD-502, Minolta; [37]). Chlorophyll fluorescence analysis was undertaken using an imaging pulse amplitude modulation (PAM) device (IMAG-MAXI; Heinz Walz, Effeltrich, Germany). 
After 20 min of dark adaption, leaves were illuminated with a saturating light pulse with a frequency of $0.05 \mathrm{~Hz}$ lasting $260 \mathrm{~s}$. The maximal photochemical efficiency of PSII (Fv/Fm) was calculated according to [38] using Imaging Win software (Heinz Walz GmbH, Effeltrich, Germany). Photosynthetic parameters including net photosynthetic rate $(P n)$, stomatal conductance $(\mathrm{Gs})$, intercellular $\mathrm{CO}_{2}$ concentration $(\mathrm{Ci})$ and transpiration rate $(\mathrm{Tr})$ were determined using an infrared analyzer (LI-6400 System; Li-COR, Lincoln, NE, USA). All measurements were performed on a sunny day between 10:00 a.m. and 1:00 p.m., with an

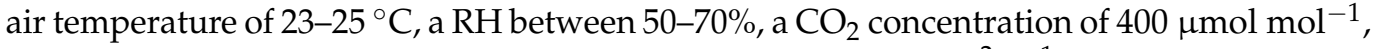
and a photosynthetic photon flux density (PPFD) of $1000 \mathrm{~mol} \mathrm{~m}^{2} \mathrm{~s}^{-1}$.

\subsection{Measurement of Elemental Concentration}

Dried shoot and root samples $(0.1 \mathrm{~g})$ were ashed at $550{ }^{\circ} \mathrm{C}$ for $12 \mathrm{~h}$. The ash was digested with $5 \mathrm{~mL}$ of $30 \% \mathrm{HNO} 3$ and then diluted using deionized water. The concentrations of $\mathrm{K}$, calcium $(\mathrm{Ca})$, magnesium $(\mathrm{Mg})$ and sodium $(\mathrm{Na})$ were determined according to [39], using a flame atomic absorption spectrometer (Shimadzu, Kyoto, Japan).

\subsection{Determination of Antioxidant Enzyme Activities and Malondialdehyde Contents}

Plants (26 days old) were harvested and immediately kept on ice, then separated into roots and shoots. Two plants from each replicate were pooled together then divided into three parts, and out of each part, $0.5 \mathrm{~g}$ was homogenized in $10 \mathrm{~mL}$ of cold $50 \mathrm{mM}$ phosphate buffer solution (PBS; pH 7.0) in an ice bath by grinding using a mortar and pestle. The homogenate was centrifuged at $4{ }^{\circ} \mathrm{C}$ for $20 \mathrm{~min}$ at 12,000 rpm. The activities of SOD (EC 1.15.1.1), CAT (EC 1.11.1.6) and POD (EC 1.11.1.7) were assayed according to [36], while APX (EC 1.11.1.11) activity was determined according to [25]. Levels of lipid peroxidation were expressed as the MDA contents following the methods of [40], where fresh plant material $(0.1 \mathrm{~g})$ from each treatment was homogenized in $2 \mathrm{~mL}$ of pre-cooled PBS. A reaction solution comprising $5 \%(w / v)$ trichloroacetic acid and thiobarbituric acid was added to the supernatants obtained after centrifugation. The absorbance of the supernatant was measured spectrophotometrically at $532 \mathrm{~nm}$ and corrected for turbidity using the absorbance at $600 \mathrm{~nm}$. ATPase activities were determined by quantitating Pi released from ATP and pyrophosphate using an activity assay kit (Jiancheng Bioengineering Institutes, ,Nanjing, China), and the procedure described by manufacturers was followed.

\subsection{Estimation of Osmoprotectants}

The sulfosalicylic acid method of [41] was employed to determine proline concentrations. Briefly, samples ( $0.1 \mathrm{~g})$ after homogenization in $5 \mathrm{~mL}$ sulfosalicylic acid $(3 \%)$ were mixed with $1.25 \%$ ninhydrin in glacial acetic acid at a ratio of $1: 2$, and after boiling at $100{ }^{\circ} \mathrm{C}$ for $30 \mathrm{~min}$ was then directly used for spectrophotometric measurement at $508 \mathrm{~nm}$. Standard curve with different proline concentrations was used for proline quantification. Determination of glycine betaine (GB) was undertaken using $0.5 \mathrm{~g}$ dried and powdered tissue samples, extracted in $\mathrm{ddH}_{2} \mathrm{O}$ for $24 \mathrm{~h}$ at $25^{\circ} \mathrm{C}$, and mechanically shaken. After filtration, $0.5 \mathrm{~mL}$ of extract was mixed with $1 \mathrm{~mL}$ of $2 \mathrm{~N} \mathrm{HCl}$ solution. Then $0.1 \mathrm{~mL}$ of cold potassium tri-iodide solution $(7.5 \mathrm{~g}$ iodine $+10 \mathrm{~g} \mathrm{KI}$ in $100 \mathrm{~mL}$ of $1 \mathrm{~N} \mathrm{HCl}$ ) was added into it and shaken in an ice bath for $90 \mathrm{~min}$ and then $2 \mathrm{~mL}$ of chilled water was poured in. Finally, $10 \mathrm{~mL}$ of 1,2-dichloroethane (chilled at $-10^{\circ} \mathrm{C}$ ) was added. From the two layers formed after 1-2 $\mathrm{min}$, the upper layer was discarded and the optical density of the lower layer was recorded at $365 \mathrm{~nm}$ [42]. Standard curve developed with different concentrations of GB was used to estimate sample GB contents. Total soluble sugars were estimated using anthrone reagent [43] using glucose as a standard, samples $(0.5 \mathrm{~g})$ were extracted 3 times with $\mathrm{ddH}_{2} \mathrm{O}\left(5 \mathrm{~mL}\right.$ each time) and 1 time with absolute ethanol for $10 \mathrm{~min}$ at $95^{\circ} \mathrm{C}$. Then the blue-green solution was measured for its optical density at $630 \mathrm{~nm}$. Soluble protein concentrations were measured by a standard assay [44], using bovine serum albumin as a standard (Bio-Rad, Hercules, CA, USA), where sample amounting to $0.5 \mathrm{~g}$ after homogenization in $5 \mathrm{~mL}$ TRIS- $\mathrm{HCl}$ buffer $(\mathrm{pH} 7.4)$ was centrifuged at $12,000 \times \mathrm{g}$ and filtered. 
Approximately, $0.02 \mathrm{~mL}$ of supernatant was utilized for the reaction which involved 2.5 $\mathrm{mL}$ of reagent $\left(100 \mathrm{mg} \mathrm{G} 250+47.5 \mathrm{~mL}\right.$ absolute ethanol $\left.+100 \mathrm{~mL} \mathrm{H}_{3} \mathrm{PO}_{4}\right)$. Readings were taken at $595 \mathrm{~nm}$ after $5 \mathrm{~min}$ reaction time.

\subsection{Assessment of Phenol, Flavonoid, Callose Content and Chitinase Activity}

Total phenolic contents (TP) were determined using $0.2 \mathrm{~g}$ frozen samples ground in $2 \mathrm{~mL}$ of $80 \%$ methanol and sand using a pestle and mortar in an ice bath followed by ultrasonication for $30 \mathrm{~min}$. The reaction system was as follows: $150 \mu \mathrm{L}$ Folin-Ciocalteu reagent (Sigma-Aldrich, Darmstadt, Germany), $200 \mu \mathrm{L}$ supernatant and $2 \mathrm{~mL} 2 \% \mathrm{Na}_{2} \mathrm{CO}_{3}$. Gallic acid was used to prepare a standard curve and absorbance was measured immediately at $735 \mathrm{~nm}$ [45]. Flavonoid contents were determined according to [46] using $0.2 \mathrm{~g}$ of frozen samples that were homogenized with $2 \mathrm{~mL} 1 \% \mathrm{HCl}$ in methanol and sonicated as above. After centrifugation, $300 \mu \mathrm{L}$ of supernatant, $300 \mu \mathrm{L} 5 \% \mathrm{NaNO}_{2}$, and $300 \mu \mathrm{L} 10 \% \mathrm{AlCl}_{3}$ were added, followed by $2 \mathrm{~mL}$ of $1 \mathrm{M} \mathrm{NaOH}$. The absorbance was measured at $510 \mathrm{~nm}$. For the quantitative measurements of callose contents, plant samples were ground and heated at $80^{\circ} \mathrm{C}$ with $1 \mathrm{M} \mathrm{NaOH}$. The homogenates were centrifuged at $1000 \times \mathrm{g}$ for $10 \mathrm{~min}$, then the supernatants were mixed with aniline blue solution ( $40 \mathrm{vol}$ of $0.1 \%$ aniline blue in water, $21 \mathrm{vol}$ of $1 \mathrm{M} \mathrm{HCl}$, and 59 vol of $1 \mathrm{M}$ glycine/ $\mathrm{NaOH}$ buffer, $\mathrm{pH} 9.5)$ and their fluorescence measured using a spectrofluorimeter (Jobin-Yvon/SPEX) as described by [47]. The plant chitinase activity was determined using an ELISA kit (Sigma-Aldrich, Darmstadt, Germany), and expressed as picomoles of 4-methylumbelliferone liberated per min and per milligram of protein.

\subsection{Secondary Metabolism-Related Enzyme Activities}

PAL activity was measured using $0.2 \mathrm{~g}$ homogenized plant samples as described by Ruiz et al. [48] and the absorbance recorded at $290 \mathrm{~nm}$. CAD activity was measured following the oxidation of hydroxycinnamyl alcohol at $30^{\circ} \mathrm{C}$ according to [49]. Absorption was measured at $400 \mathrm{~nm}$ with an interval of $20 \mathrm{~s}$ and an absorption coefficient of $21 \mathrm{mM} \mathrm{cm}^{-1}$. PPO activity was determined according to [48]. Shikimate dehydrogenase (SKDH) was determined according to [50]; absorption was measured at $340 \mathrm{~nm}$ with an interval of $20 \mathrm{~s}$ and an absorption coefficient of $6.22 \mathrm{mM} \mathrm{cm}^{-1}$. Protein contents were quantified according to [44] using bovine serum albumin as a standard. The spectrophotometric analyses were conducted in 96-well Corning ${ }^{\circledR}$ Costar ${ }^{\circledR 96-W e l l ~ C e l l ~ c u l t u r e ~ p l a t e s ~(S i g m a-A l d r i c h, ~}$ Darmstadt, Germany).

\subsection{Total RNA Extraction, cDNA Synthesis and qRT-PCR Assay}

Total RNA was extracted from $100 \mathrm{mg}$ of leaf tissue using the Takara MiniBEST Plant RNA Extraction Kit (Takara, Tokyo, Japan) according to the manufacturer's instructions. RNA concentrations were measured using a Titertek-Berthold nanospectrometer (Pforzheim, Germany), and for RNA quality assay, the samples were electrophoresed in a $1 \%$ agarose gel using $1 \times$ TAE as the running buffer. A Prime script RT reagent Kit (Takara, Tokyo, Japan) was used for cDNA synthesis. The cDNA samples were assayed by quantitative real time PCR (qRT-PCR) in a Light Cycler ${ }^{\circledR} 480$ II Real-Time PCR System (Roche, Basel, Switzerland) using the SYBR ${ }^{\circledR}$ Premix Ex Taq ${ }^{\mathrm{TM}}$ II (Takara, Tokyo, Japan). The primers used for the amplification of target cDNAs were designed using the barley genome available at the National Center for Biotechnology Information (https:/ / www. ncbi.nlm.nih.gov / pubmed, accessed on 7 September 2020). The software provided with the PCR system was used to calculate threshold cycle values, and quantification of mRNA levels was performed according to the method of [51]. The HvActin gene (accession number AY145451) was amplified with the primer pair, 5'TTCTCGACTCTGGTGATGGTGT3' and $5^{\prime}$ CAAGCTTCTCCTTGATGTCCCT3 ${ }^{\prime}$, as an internal control for the relative amount of RNA. The specific primers used in this experiment are presented in Table S11. 


\subsection{Statistical Analysis}

All data are presented as the mean values. Analysis of variance (ANOVA) was performed to determine statistical differences among the treatments. The significance level for the difference between Tibetan wild and cultivated barley genotypes, and among the control and K and D treatments were determined using LSD tests at $(p<0.05)$ via the Data Processing System (DPS) Software Package [52]. Graphical representations were prepared using Origin Pro version 2019b (Origin Lab Corporation, Wellesley Hills, Wellesley, MA, USA).

\section{Conclusions}

A comparative tolerance to the combined effect of drought and $\mathrm{K}+$ deficiency has been displayed by the Tibetan wild barley XZ5, and to a certain extent cv. Tadmor, relative to the drought susceptible genotype XZ54. However, improved K+ nutrition remains pivotal for promoting plant growth and mitigating the harsh effects of drought stress. Observations led to a conclusion that tolerant varieties tend to make the most of available $\mathrm{K}+$ by its quick translocation to the shoot which improves overall water use efficiency. Stress tolerance is also mediated by multiple traits including maintenance of the photosynthetic apparatus, reduction in the effects of ROS, increased Ca accumulation in shoots to trigger stomatal closure, and production of compatible solutes suggesting that these traits may also mediate tolerance to a wide spectrum of abiotic stresses. Thus, our results add further evidence to support the concept that Tibetan wild barley is a valuable resource of genes for improved $\mathrm{K}$ metabolism in addition to those for combating drought stress. The exploitation of these genes will enable the development of elite barley lines better tolerant to abiotic stresses.

Supplementary Materials: The following are available online at https://www.mdpi.com/article/10 $.3390 /$ ijms222313100/s1.

Author Contributions: F.W. and Y.W. conceived and designed the study. S.S., M.F.A. and M.Z. performed the experiments. S.S. wrote the paper. P.H., F.C., Y.W. and F.W. reviewed and edited the manuscript. All authors have read and agreed to the published version of the manuscript.

Funding: This project was supported by the National Natural Science Foundation of China (31871537) , the Zhejiang Provincial Natural Science Foundation (LR21C0001), the Key Research Foundation of Science and Technology Department of Zhejiang Province of China (2021C02064-3; 2016C02050-9-7), and the Fundamental Research Funds for the Central Universities (2020XZZX002-21).

Institutional Review Board Statement: Not applicable.

Informed Consent Statement: Not applicable.

Data Availability Statement: All data supporting the conclusions of the present study have been documented in this article.

Acknowledgments: The authors would like to thank Ghulam Jilani (PMAS Arid Agriculture University Rawalpindi, Pakistan) and Paul Milham (Western Sydney University, Australia) for their comments on the manuscript.

Conflicts of Interest: The authors declare no conflict of interest.

\section{References}

1. Etesami, H.; Maheshwari, D.K. Use of plant growth promoting rhizobacteria (PGPRs) with multiple plant growth promoting traits in stress agriculture: Action mechanisms and future prospects. Ecotoxicol. Environ. Saf. 2018, 156, 225-246. [CrossRef]

2. Rastegari, A.A.; Yadav, A.N.; Awasthi, A.A.; Yadav, N. Trends of Microbial Biotechnology for Sustainable Agriculture and Biomedicine Systems: Diversity and Functional Perspectives; Elsevier: Amsterdam, The Netherlands, 2020.

3. He, X.; Zeng, J.; Cao, F.; Ahmed, I.M.; Zhang, G.P.; Vincze, E.; Wu, F.B. HvEXPB7, a novel $\beta$-expansin gene revealed by the root hair transcriptome of Tibetan wild barley, improves root hair growth under drought stress. J. Exp. Bot. 2015, 66, 7405-7419. [CrossRef]

4. Vurukonda, S.S.K.P.; Vardharajula, S.; Shrivastava, M.; SkZ, A. Enhancement of drought stress tolerance in crops by plant growth promoting rhizobacteria. Microbiol. Res. 2016, 184, 13-24. [CrossRef] [PubMed] 
5. Khan, N.; Zandi, P.; Ali, S.; Mehmood, A.; Adnan, S.M. Impact of salicylic acid and PGPR on the drought tolerance and phytoremediation potential of Helianthus annus. Front. Microbiol. 2018, 9, 2507. [CrossRef]

6. Ahmed, I.M.; Cao, F.; Zhang, M.; Chen, X.; Zhang, G.; Wu, F.B. Difference in yield and physiological features in response to drought and salinity combined stress during anthesis in Tibetan wild and cultivated barleys. PLoS ONE 2013, 8, e77869.

7. Kishori, K.; Polavarapu, B.; Sreenivasulu, N. Is proline accumulation per se correlated with stress tolerance or is proline homeostasis a more critical issue? Plant Cell Environ. 2014, 37, 300-311. [CrossRef]

8. Kaushal, M.; Wani, S.P. Plant-growth-promoting rhizobacteria: Drought stress alleviators to ameliorate crop production in drylands. Ann. Microbiol. 2016, 66, 35-42. [CrossRef]

9. Sharma, P.; Jha, A.B.; Dubey, R.S.; Pessarakli, M. Reactive oxygen species, oxidative damage, and antioxidative defense mechanism in plants under stressful conditions. J. Bot. 2012, 1, 1-26. [CrossRef]

10. Faralli, M.; Lektemur, C.; Rosellini, D.; Gürel, F. Effects of heat shock and salinity on barley growth and stress-related gene transcription. Biol. Plant. 2015, 59, 537-546. [CrossRef]

11. Farooq, M.; Wahid, A.; Kobayashi, N.; Fujita, D.; Basra, S.M.A. Plant drought stress: Effects, mechanisms and management. Agron. Sustain. Dev. 2009, 29, 185-212. [CrossRef]

12. Guo, P.; Baum, M.; Grando, S.; Ceccarelli, S.; Bai, G.; Li, R.; Korff, M.V.; Varshney, R.K.; Graner, A.; Valkoun, J. Differentially expressed genes between drought-tolerant and drought-sensitive barley genotypes in response to drought stress during the reproductive stage. J. Exp. Bot. 2009, 60, 3531-3544. [CrossRef]

13. Coskun, D.; Britto, D.T.; Kronzucker, H.J. The physiology of channel-mediated $\mathrm{K}^{+}$acquisition in roots of higher plants. Physiol. Plant. 2014, 151, 305-312. [CrossRef] [PubMed]

14. Wang, Y.; Blatt, M.R.; Chen, Z.H. Ion transport at the plant plasma membrane. eLS 2018, 1-6.

15. Wang, M.; Zheng, Q.; Shen, Q.; Guo, S. The critical role of potassium in plant stress response. Int. J. Mol. Sci. 2013, 14, 7370-7390. [CrossRef]

16. Zhao, J.; Sun, H.; Dai, H.; Zhang, G.P.; Wu, F.B. Difference in response to drought stress among Tibet wild barley genotypes. Euphytica 2010, 172, 395-403. [CrossRef]

17. Dai, F.; Chen, Z.; Wang, X.; Li, Z.; Jin, G.; Wu, D.; Cai, S.; Wang, N.; Wu, F.; Nevo, E.; et al. Transcriptome profiling reveals mosaic genomic origins of modern cultivated barley. Proc. Natl. Acad. Sci. USA 2014, 111, 13403-13408. [CrossRef] [PubMed]

18. Ahmed, I.M.; Cao, F.B.; Han, Y.; Nadira, U.A.; Zhang, G.P.; Wu, F.B. Differential changes in grain ultrastructure, amylase, protein and amino acid profiles between Tibetan wild and cultivated barleys under drought and salinity alone and combined stress. Food Chem. 2013, 141, 2743-2750. [CrossRef]

19. Liu, H.; Zhang, J.; Liu, J.; Su, Q.; Zhang, Q.; Gao, Y.; Yang, C. Study of the physiological mechanisms of two species of Spiraea during adaptation to drought treatment. Acta Physiol. Plant. 2017, 39, 186. [CrossRef]

20. Su, L.; Dai, Z.; Li, S.; Xin, H. A novel system for evaluating drought-cold tolerance of grapevines using chlorophyll fluorescence. BMC Plant Biol. 2015, 15, 82. [CrossRef]

21. Ye, Z.L.; Zeng, J.B.; Li, X.; Zeng, F.R.; Zhang, G.P. Physiological characterizations of three barley genotypes in response to low potassium stress. Acta Physiol. Plant. 2017, 39, 232. [CrossRef]

22. James, R.A.; Munns, R.; Von Caemmerer, S.; Trejo, C.; Miller, C.; Condon, T. Photosynthetic capacity is related to the cellular and subcellular partitioning of $\mathrm{Na}^{+}, \mathrm{K}^{+}$and $\mathrm{Cl}^{-}$in salt-affected barley and durum wheat. Plant Cell Environ. 2006, 29, $2185-2197$. [CrossRef]

23. Tuteja, N.; Mahajan, S. Calcium signaling network in plants: An overview. Plant Signal. Behav. 2007, 2, 79-85. [CrossRef]

24. Tadayyon, A.; Nikneshan, P.; Pessarakli, M. Effects of drought stress on concentration of macro- and micro-nutrients in Castor (Ricinus communis L.) plant. J. Plant Nutr. 2018, 41, 304-310. [CrossRef]

25. Chen, F.; Wang, F.; Wu, F.; Mao, W.; Zhang, G.; Zhou, M. Modulation of exogenous glutathione in antioxidant defense system against Cd stress in the two barley genotypes differing in Cd tolerance. Plant Physiol. Biochem. 2010, 48, 663-672. [CrossRef] [PubMed]

26. Oliveira, J.; Mateus, N.; de Freitas, V. Flavanols: Catechins and Proanthocyanidins. In Natural Products; Ramawat, K., Mérillon, J.M., Eds.; Springer: Berlin/Heidelberg, Germany, 2013.

27. Hura, T.; Grzesiak, S.; Hura, K.; Thiemt, E.; Tokarz, K.; Wędzony, M. Physiological and biochemical tools useful in droughttolerance detection in genotypes of winter triticale: Accumulation of ferulic acid correlates with drought tolerance. Ann. Bot. 2007, 100, 767-775. [CrossRef] [PubMed]

28. Yang, Y.; Wang, Y.; Jia, L.; Yang, G.; Xu, X.; Zhai, H.; He, S.; Li, J.; Dai, X.; Qin, N.; et al. Involvement of an ABI-like protein and a $\mathrm{Ca}^{2+}$-ATPase in drought tolerance as revealed by transcript profiling of a sweet potato somatic hybrid and its parents Ipomoea batatas (L.) Lam. and I. triloba L. PLoS ONE 2018, 3, e0193193. [CrossRef] [PubMed]

29. Morsomme, P.; Boutry, M. The plant plasma membrane $\mathrm{H}^{+}$-ATPase: Structure, function and regulation. Biochim Biophys Acta Biomembr. 2000, 1465, 1-16. [CrossRef]

30. Acosta-Motos, J.; Ortuño, M.; Bernal-Vicente, A.; Diaz-Vivancos, P.; Sanchez-Blanco, M.; Hernandez, J. Plant responses to salt stress: Adaptive mechanisms. Agronomy 2017, 7, 18. [CrossRef]

31. Li, S.; Yamada, M.; Han, X.; Ohler, U.; Benfey, P.N. High-resolution expression map of the Arabidopsis root reveals alternative splicing and lincRNA regulation. Dev. Cell 2016, 39, 508-522. [CrossRef] 
32. Preisner, M.; Wojtasik, W.; Kostyn, K.; Boba, A.; Czuj, T.; Szopa, J.; Kulma, A. The cinnamyl alcohol dehydrogenase family in flax: Differentiation during plant growth and under stress conditions. J. Plant Physiol. 2018, 221, 132-143. [CrossRef] [PubMed]

33. Liu, W.; Jin, Y.; Li, M.; Dong, L.; Guo, D.; Lu, C.; Qi, H. Analysis of CmCADs and three lignifying enzymes in oriental melon ('CaiHong7') seedlings in response to three abiotic stresses. Sci. Hortic. 2018, 237, 257-268. [CrossRef]

34. Kumar, S.A.; Kumari, P.H.; Jawahar, G.; Prashanth, S.; Suravajhala, P.; Katam, R.; Sivan, P.; Rao, K.S.; Kirti, P.B.; Kishor, P.K. Beyond just being foot soldiers-Osmotin like protein (OLP) and chitinase (Chi11) genes act as sentinels to confront salt, drought, and fungal stress tolerance in tomato. Environ. Exp. Bot. 2016, 132, 53-65. [CrossRef]

35. Nedukha, O.M. Callose: Localization, functions, and synthesis in plant cells. Cytol. Genet. 2015, 49, 49-57. [CrossRef]

36. Wu, F.B.; Zhang, G.P.; Dominy, P. Four barley genotypes respond differently to cadmium: Lipid peroxidation and activities of antioxidant capacity. Environ. Exp. Bot. 2003, 50, 67-78. [CrossRef]

37. Wu, F.B.; Wu, L.H.; Xu, F.H. Chlorophyll meter to predict nitrogen side dress requirements for short-season cotton (Gossypium hirsutum L.). Field Crops Res. 1998, 56, 309-314.

38. Genty, B.; Briantais, J.M.; Baker, N.R. The relationship between the quantum yield of photosynthetic electron transport and quenching of chlorophyll fluorescence. Biochim. Biophys. Acta Biomembr. 1989, 990, 87-92. [CrossRef]

39. Chen, F.; Wu, F.B.; Dong, J.; Vincze, E.; Zhang, G.P.; Wang, F.; Huang, Y.Z.; Wei, K. Cadmium translocation and accumulation in developing barley grains. Planta 2007, 227, 223-232. [CrossRef] [PubMed]

40. Zhang, H.Y.; Jiang, Y.N.; He, Z.Y.; Ma, M. Cadmium accumulation and oxidative stress burst in garlic (Allium sativum). J. Plant Physiol. 2005, 162, 977-984. [CrossRef]

41. Shabnam, N.; Tripathi, I.; Sharmila, P.; Pardha-Saradhi, P. A rapid, ideal, and eco-friendlier protocol for quantifying proline. Protoplasma 2015, 253, 1577. [CrossRef] [PubMed]

42. Greive, C.M.; Grattan, S.R. Rapid assay for determination of water-soluble quaternary-amino compounds. Plant Soil 1983, 70, 303-307. [CrossRef]

43. Irigoyen, J.J.; Emerich, D.W.; Sanches-Diaz, M. Water stress induced changes in concentrations of proline and total soluble sugars in nodulated alfalfa (Medicago sativa) plants. Physiol. Plant 1992, 84, 55-60. [CrossRef]

44. Bradford, M.M. A rapid and sensitive method for the quantitation of microgram 1uantities of protein utilizing the principle of protein-dye binding. Anal. Biochem. 1976, 72, 248-254. [CrossRef]

45. Singleton, V.L.; Orthofer, R.; Lamuela-Raventos, R.M. Analysis of total phenols and other oxidation substrates and antioxidants by means of Folin-Ciocalteu reagent. Methods Enzymol. 1999, 299, 152-178.

46. Zhishen, J.; Mengcheng, T.; Jianming, W. The determination of flavonoid contents in mulberry and their scavenging effects on superoxide radicals. Food Chem. 1999, 64, 555-559. [CrossRef]

47. Shedletzky, C.U.; Delmer, D.P. A microtiter-based fluorescence assay for (1,3)- $\beta$-glucan synthases. Anal. Biochem. 1997, $249,88-93$. [CrossRef] [PubMed]

48. Ruiz, J.M.; Garcia, P.C.; Rivero, R.M.; Romero, L. Response of phenolic metabolism to the application of carbendazim plus boron in tobacco. Physiol. Plant. 1999, 106, 151-157. [CrossRef]

49. Mitchell, H.J.; Hall, J.; Barber, M.S. Elicitor-induced cinnamyl alcohol dehydrogenase activity in lignifying wheat (Triticum aestivum L.) leaves. Plant Physiol. 1994, 104, 551-556. [CrossRef]

50. Diaz, J.; Bernal, A.; Pomar, F.; Merino, F. Induction of shikimate dehydrogenase and peroxidase in pepper (Capsicum annuum L.) seedlings in response to copper stress and its relation to lignification. Plant Sci. 2001, 161, 179-188.

51. Schmittgen, T.D.; Livak, K.J. Analyzing real-time PCR data by the comparative CT method. Nat. Protoc. 2008, 3, 1101-1108. [CrossRef]

52. Tang, Q.Y.; Feng, M.G. Practical Statistics and Its DPS Statistical Software Package; China Agriculture Press: Bejing, China, 1997. 